\title{
WestVirginiaUniversity
}

THE RESEARCH REPOSITORY @ WVU

Graduate Theses, Dissertations, and Problem Reports

2009

\section{Spillover effects in financial and international development}

John Dogbey

West Virginia University

Follow this and additional works at: https://researchrepository.wvu.edu/etd

\section{Recommended Citation}

Dogbey, John, "Spillover effects in financial and international development" (2009). Graduate Theses, Dissertations, and Problem Reports. 4457.

https://researchrepository.wvu.edu/etd/4457

This Dissertation is protected by copyright and/or related rights. It has been brought to you by the The Research Repository @ WVU with permission from the rights-holder(s). You are free to use this Dissertation in any way that is permitted by the copyright and related rights legislation that applies to your use. For other uses you must obtain permission from the rights-holder(s) directly, unless additional rights are indicated by a Creative Commons license in the record and/ or on the work itself. This Dissertation has been accepted for inclusion in WVU Graduate Theses, Dissertations, and Problem Reports collection by an authorized administrator of The Research Repository @ WVU.

For more information, please contact researchrepository@mail.wvu.edu. 
Spillover Effects in Financial and International Development

\author{
John Dogbey
}

Dissertation submitted to the

College of Business and Economics

at West Virginia University in partial

fulfillment of the requirements for

the degree of

Doctor of Philosophy

in

Economics

Russell Sobel, Ph.D., Chair

Subhayu Bandyopadhyay, Ph.D.

Chris Coyne, Ph.D.

Stratford Douglas, Ph.D.

Alexei Egorov, Ph.D.

\title{
Division of Economics and Finance \\ Morgantown, West Virginia \\ 2009
}

Key Words: contagion, spillover effects, financial development, currency crises, fractionalization 


\section{Abstract \\ Spillover Effects in Financial and International Development}

John Dogbey

The main objective of this dissertation is to explore some possible externalities that exist in the international context in the areas of finance and development economics. Chapter one is an introduction to this study. Chapter two examines contagion in exchange market pressure, currency crisis and currency stability. In this chapter I test whether exchange market pressure, in general, is contagious and proceed to test separately for contagion in currency crisis and currency stability. I construct an index of exchange market pressure for a panel of 118 countries and choose a threshold from which positive or negative deviations denote currency crisis and currency stability respectively.

The need to test for contagion in currency stability is to find out whether contagion is only a crises phenomenon. Currency crisis and currency stability spread by geography, trade and financial markets. Using spatial econometric models and constructing the appropriate trade and geography weight matrixes, I estimate the magnitude of the contagion by trade and geography respectively. I find that both transmission mechanisms do significantly transmit currency crisis and currency stability, but trade is more contagious than geography alone. I also find that currency stability is more contagious than currency stability. The results also suggest that trade channel is solely responsible for contagious currency crises that are not regional while the combination of the trade and geography channels of transmission are responsible for the prevalent nature of regional contagious currency crises.

In chapter three I test for contagion in financial development both in levels and in change of financial development. The main measure of financial development considered for this analysis is domestic banking, but I use banking development and stock market development in some cases for robustness checks. I define domestic banking development as domestic credit to the private sector as a percentage of GDP. I explain contagion channels of geography, trade and financial linkages and, using spatial econometric models, test for these for a panel of 98 countries for the geography and trade regressions and a panel of 30 countries (OECD countries) for the financial linkages regression. The results show that financial development and change of financial development are contagious of almost the same magnitude. I also find that the greatest channel of contagion is financial linkages followed closely by trade and geography. The results also suggest that other control variables such as bureaucratic quality and legal environment are important for financial development.

In chapter four, I empirically investigate why ethno-linguistic fractionalization has not dissipated in African countries. This is based on the idea that if trade spreads economic events across countries that engage in trade, why do we not have a single or few dominant language(s) spreading through the African continent? Similarly, why does geography not help propagate such things as a lingua in Africa?

The chapter explains that one of the main factors that have perpetuated ethno-linguistic fractionalization in Africa is colonial rule. Countries and or regions that have long years of colonial rule may be fractionalized than countries and regions with shorter years of colonial rule. Second, colonial barriers have helped perpetuate the fractionalization by limiting trade among African countries, even in the face of increasing globalization. I investigate this in a regression that measures colonial rule as the number of years a country has been colonized while 
controlling for other determinants of ethno-linguistic fractionalization. In chapter five, I summarize the conclusions of the study. 


\section{Acknowledgements}

My most gratitude goes to my advisor, Prof. Russell Sobel for his indispensable guide and support throughout my research. His suggestions, comments and expertise enriched my knowledge and work. Special thanks to Prof. Coyne for useful comments and suggestions and for providing me with data that was very helpful for my research. My thanks go to Prof. Egorov as well for help with econometrics and statistical programming guide. I would also want to thank Prof. Douglas and Dr. Subhayu for useful comments and suggestions. Many thanks to Prof. Hawley for funding my conference trips with funds from the Economics Department. Last but not least, my gratitude goes to all conference participants for their helpful feedback. The standard disclaimer applies. 
To my parents for their matchless motivation and encouragement 


\section{Table of Contents}

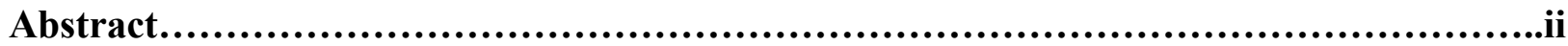

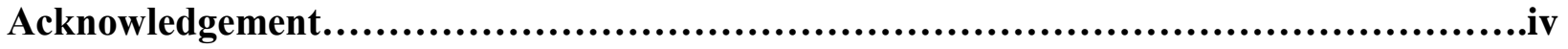

List of Tables...............................................................................

1. Introduction, and Review of Literature..............................................

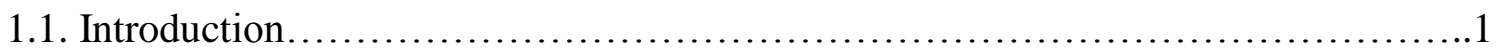

1.2. Literature Review......................................................

1.3. Dissertation Overview ...................................................6

2. Currency Crises and Exchange Market Pressure - Contagion, Trade and Geography....9

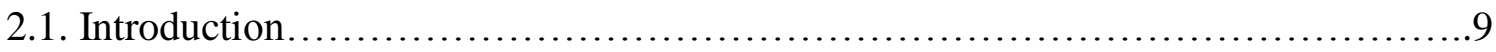

2. 2. Channels of Transmission................................................. 12

2.2.1. Geography ...................................................... 12

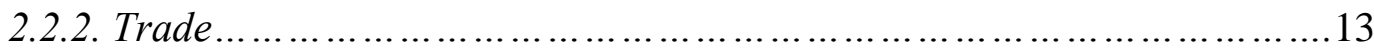

2.2.3. Financial Markets ........................................................... 14

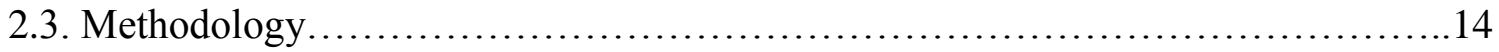

2.3.1. Model .................................................................... 14

2.3.2. Measuring the Dependent Variables.......................................16

2.3.3. Constructing the Weight Matrices ........................................ 18

2. 3.4. Independent Variables ................................................22

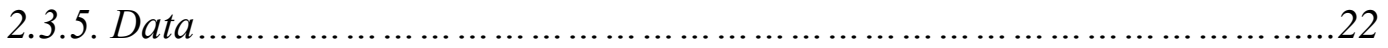

2.4. Results............................................................. 23

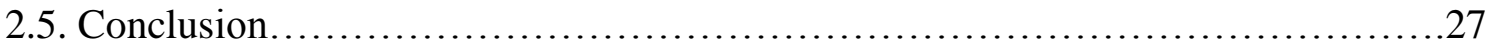

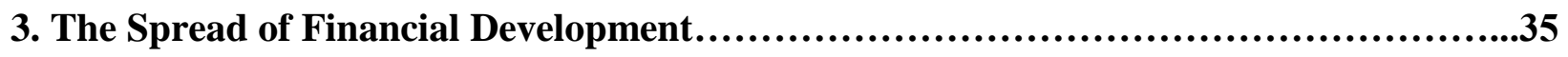

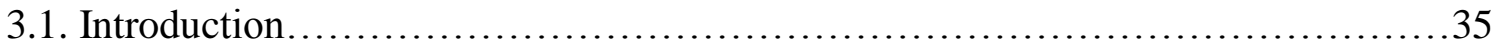


3.2. Transmission Mechanisms of Financial Development..............................37

3.2.1. Geography as a channel of Financial Development ..........................37

3.2.2. Trade as a channel of Financial Development..............................38

3.2.3. Financial Linkages as a channel of Financial Development ..................38

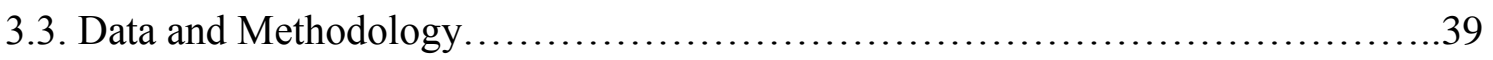

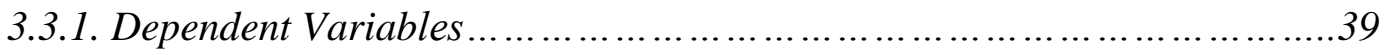

3.3.2. Independent Variables.................................................4 40

3.3.3. Methodology ..................................................... 41

3.3.4. Weight Matrixes....................................................... 42

3.4. Results......................................................... 44

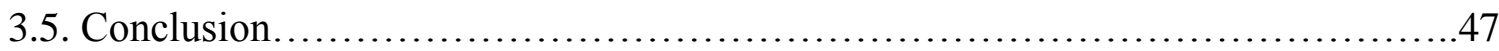

4. Is Ethno-linguistic Fractionalization Perpetuated in Africa? .........................................51

4.1. Introduction....................................................... 51

4.2. Possibility of Ethno-Linguistic Fractionalization Decline in Pre-Colonial Africa.........53

4.2.1. Pre-colonial Africa and Ethno-linguistic Decline .............................53

4.2.2. Cost and Benefits of Learning a New Language in Pre-colonial Africa ............55

4.3. The Worsening of Ethno-linguist Fractionalization during Colonial Rule ................57

4.4. Methodology ..............................................................61

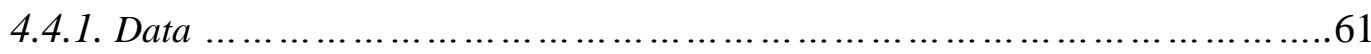

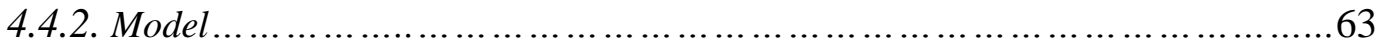

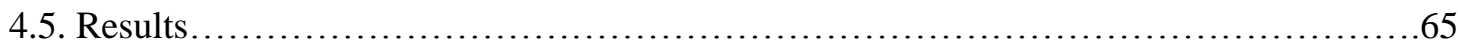

4.6. Is there a Possibility of Linguistic Homogeneity in Post-colonial Africa?.....................66

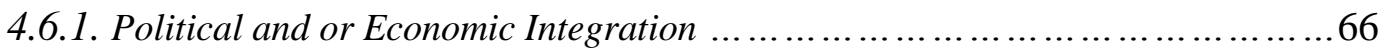

4.6.2. Costs and Benefits of Implementing Policies that could Reduce Ethno- 
linguistic Fractionalization ..................................................66

4.7. Conclusion.......................................................68

5. Conclusion....................................................................................74

References................................................................................76

Appendix 1: Variable Description, Descriptive Statistics, and Sources for chapter 3..........80

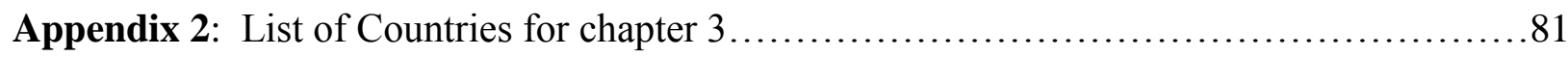

Appendix 3: Variable Description, Descriptive Statistics, and Sources for chapter 4...........82

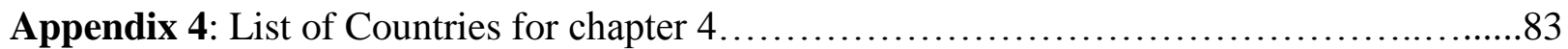

Appendix 5: Variable Description, Descriptive Statistics, and Sources for chapter 5..........84

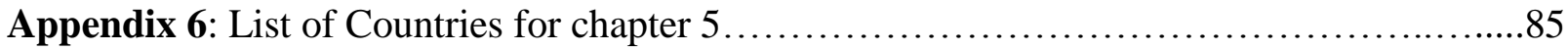




\section{List of Tables}

Table 1.1: Contagion- Exchange Market Pressure.........................................29

Table 1.2: Contagion- Currency Crisis............................................ 30

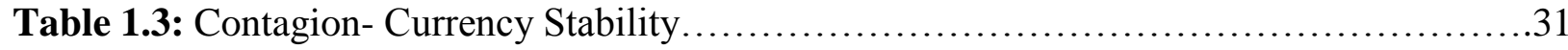

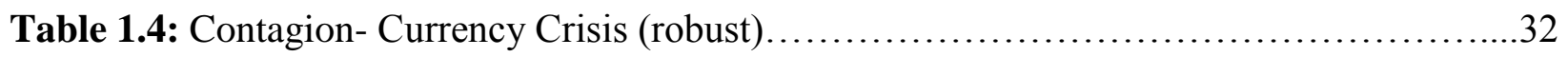

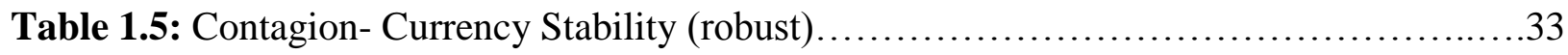

Table 1.6: Contagion - Using Dummy Dependent Variables................................ 34

Table 2.1: Geographic Contagion $\ldots \ldots \ldots \ldots \ldots \ldots \ldots \ldots \ldots \ldots \ldots \ldots \ldots \ldots \ldots \ldots \ldots \ldots \ldots \ldots \ldots$

Table 2.2: Trade Contagion....................................................49

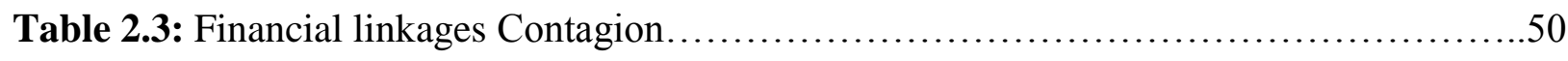

Table 3.1: Ethno-linguistic Fractionalization...................................... 70

Table 3.2: Ethno-linguistic Fractionalization, institutions and other colonization measures......71

Table 3.3: Linguistic Fractionalization........................................... 72

Table 3.4: Linguistic Fractionalization with institutions and other colonization measures.......73 


\section{CHAPTER 1}

\section{Introduction, Review of Literature and Dissertation Overview}

\subsection{Introduction}

The global economy has seen a lot of spillovers usually referred to as economic contagion. The term "spillover" or "contagion" in an international context means shocks coming from a related country or an event that affects most or all countries in the world. Such events obviously include currency crises and financial crises such as credit freezes. Other less conspicuous contagious events are currency stability, and the spread of or the evolution of a common language or trade language among societies.

Chiodo and Owyang (2002) define currency crisis as a speculative attack on a country's currency brought about by agents attempting to alter their portfolio by buying another currency with the currency of the domestic country. There are three generations of currency crises and four factors that cause and exacerbate currency crises namely domestic debt, pegged exchange rate, expectations, and the state of financial markets.

For the first generation model, Pesenti and Tille (2000) explain that when governments have huge debts under fixed exchange rate regimes, it makes economic agents doubt the government's ability to sustain the peg and hence sell the local currency to hold foreign currency against possible devaluation. This is also possible during government bailouts as pointed out by Calvo and Mendoza (1996).

The second generation model explains that geographic neighbors, trade partners and the world's financial markets are responsible for the spread of currency crises. Pesenti and Tille (2000) explain that when foreign investors expect devaluations, they will ask a high premium 
which increases borrowing cost and limits credit opportunities and governments abandon the peg. The third generation model explains that because the banks and the financial markets are fragile, increases in interest rates makes firms' default rate high, and this becomes lending constraints. Kaminsky and Reinhart (1996) explain the twin problem between the banking sector and currency crises.

Financial development is believed to have played a great role in the economic growth of many countries during the recent trend towards globalization. Stulz (2005) points out that high risks of expropriation and thus insecure property rights limit financial development and the ability of a country to take advantage of financial globalization. Johnson, McMillan and Woodruff (2002) show the positive relationship between private sector enforcement, financial development and investment and growth.

Bekaert, Harvey, and Lundblad (2005) show that the effect of liberalization on economic growth is greater if a country starts from above average level of financial development. Also, Bekaert, Harvey, Lundblad and Siegel (2007) find that domestic banking development is one of the important requirements in exploiting growth opportunities. Hermes and Lensink (1999) explore the relationship between growth, FDI and financial development and conclude that financial development is one of the prerequisites for a country to realize the full growth potential of FDI.

Aghion, Howitt, and Mayer-Fulkes (2003) provide an empirical evidence supporting the Schumpeterian Theory of Convergence and conclude that countries with a certain critical level of financial development have a likelihood of converging to the world-technology frontier and that other countries have far lower long-run growth. 
Ethno-linguistic fractionalization has received a lot of attention in the development literature. Specifically, most people believe that it is one of the problems that contribute to the demise of the African continent in particular. Poor institutions are primarily responsible for fractionalization in Africa. In other words, by controlling for institutions the negative impact of institutions on growth disappears. Colonial artificial institutions are also responsible for the limited trade in Africa and the resultant poor growth (Leeson, 2005; Easterly, 2001; Easterly and Levine, 1997).

The relationship between colonial rule and growth has also been explored. Different measures of colonization have been found to account for poor growth in Africa. These measures include the length of colonial rule, colonial penetration and colonial history.

\subsection{Literature Review}

The literature review consists of brief review of the empirical literature of each topic and a discussion of my contribution to the existing literature. In the currency crises literature, Edwards (2000) employ VAR to investigate volatility contagion. Eichengreen, Rose and Wyplosz (1996) and Glick and Rose (1999) employ probit models to address contagion in currency crises. The later two literature use dummies as the measures of currency crisis and hence probit estimation procedures to find the presence and or magnitude of the contagion.

This is the first study that uses a spatial econometric model to study contagion in currency crises. The hallmark of chapter 2 is that it attempts to measure trade and geographic channels of currency crises transmission separately as well as examine the effects of economic fundamentals on currency crises (the extent to which economic fundamentals aggravate currency crises in a country). This model has the advantage of accounting for multi-directional effects as 
opposed to unidirectional effects captured in the conventional econometrics models. In addition, it is also convenient for situations where spatial dependence exists in the data.

This study produce evidence supporting the hypothesis that trade is contagious in transmitting currency crises and or exchange market pressure from one country to the other and that it does so to a larger extent than existing findings. Second, this chapter also examines whether contagion is only crises phenomenon. It shows that there is contagion during strong and stable currency periods, the impact through trade and geographic linkages is positive and that trade linkages have a larger magnitude in this case than during currency crises. For geography, the magnitude is same as during currency crises.

Also, this study examines whether macroeconomic channels are economically significant in explaining currency crises or exchange market pressure. The findings suggest that trade has been the dominant factor to which geography is next. These two channels explain why during currency crises, some countries are infected while some are not. For example, it explains why during the Asian Crisis in 1997-98 countries like Russia and some Asian countries were prey to the endemic crisis, but countries like Taiwan, Hong Kong and Singapore were not infected even though they are in the same region. Or, why the Tequila Crisis in Latin America during 1994-95 infected other Latin American countries and Hungary but did not affect Chile.

This chapter poses the question, given that a country experiences currency crises or some level of exchange market pressure, what percentage of it is attributable to trade channels or geographic channels?

In the financial development literature, a lot of studies use financial development as exogenous variable to either explain growth, FDI or other economic variables. Much more related to this study which endogenizes financial development is Koubi (2008). In his study, he 
controlled for initial per-capita GDP, legal environment and bureaucratic quality to find how these variables determined financial development.

This study tests whether the amount of private credit being advanced to the private sector in one country depends on what is prevailing in the private credit markets of other countries. Second, it attempts to find out what the transmission mechanisms are and what the magnitude of the contagion is in each case. The Schumpeterian theory of convergence propounds that countries beyond a certain level of financial development converge to the world technology frontier. This chapter therefore examines how countries attain the necessary level of financial development needed for growth convergence. It identifies three channels of contagion in financial development namely financial linkages, trade and geography.

My results suggest that each of these is a significant channel through which financial development can spread from one country to the other. Specifically, it finds which channel is more effective and more responsible for the spread and growth of financial development in countries. Whiles no single channel seem to be the sole means of transmission, my results show that financial linkages is a more effective means followed closely by trade and geography.

The ethno-linguistic fractionalization literature also comprises of quite a lot of papers that use ethno-linguistic fractionalization as an exogenous variable. One related study that endogenizes ethno-linguistic fractionalization is Leeson (2005), but it is not an empirical study.

This study empirically examines how ethno-linguistic fractionalization is determined and explains why it seems to be perpetuated in some regions of the world, specifically on the continent of Africa. 


\subsection{Dissertation Overview}

This study focuses on economic contagion in the areas of financial and economic development. In other words, the main objective of this dissertation is to explore some possible externalities that exist in the international context in the areas of finance and economic development.

The dissertation uses spatial econometric models to measure contagion. Spatial econometric models are especial appropriate and useful when there exists spatial dependence in the data under consideration. The two types of spatial models are spatial error model and spatial autoregressive model. Spatial autoregressive model (SAR) specifies a country's dependent variable as a function of the weighted value of the dependent variable of its neighbors or partners. It takes lags over geographic distance. Spatial error model (SEM) specifies the error term of a country's dependable variable as a function of the weighted value of the dependent variable of its geographic neighbors or partners. The dissertation also uses OLS specifications as well as seeming unrelated models to estimate certain variables. The rest of the dissertation is organized as follows: chapter 2, 3, and 4 presents the empirical work and chapter 5 summarizes the findings of the study.

Chapter 2 looks at contagion in the area of exchange market pressure. It asks whether exchange market pressure, currency crisis, and currency stability are contagious. Decomposing geographic channels and trade channels of currency crises provides the ability to answer two questions in the currency crises literature. The first is why are currency crises regional? The second is why do some countries not within geographical locations of currency crises zones get infected while some closer do not get infected? For example, why the Tequila Crisis in Latin America during 1994-95 infected Hungary and other Latin American countries but did not affect Chile? 
The chapter finds that because the geographic channel is not as strong as the trade channel, a distant country that has trade links with the infected country is more likely to be infected than a neighbor who has no trade links with the infected country. Also crises are regional because neighbors do have some minimal trade linkages and this together with the geography linkages produces an amalgamating effect that is usually bigger than the magnitude of trade linkages alone. Also he found that contagion is not only crises phenomenon but is more pronounced during stable and strong currency period, especially by trade.

Chapter 3 studies contagion in financial development, exploring the possibilities of contagion in financial development both at levels and change of financial development. The chapter answers the question how do countries attain the necessary level of financial development needed for growth convergence? It identified three channels of financial development namely financial linkages, trade and geography.

By geography, financial development spreads through economic unions and through the activities of common lenders to regional blocks. Through the activities of institutional investors economic unions such as the EU can increase the level of financial development of its members Cvetanovic (2006). Financial linkages could spread financial development either directly or indirectly. Directly, financial linkages can take the form of establishment of foreign banks and financial instructions. Indirectly, domestic lenders have the opportunity to learn the expertise (such as the ability to distinguish good credit risks from bad credit risks) from these foreign lenders and hence be in a better position to advance more credit. Competition with the foreign banks for customers can also results in a higher level of financial development. Finally trade liberalization and globalization leads to competition with the outside world making domestic entrepreneurs put pressure on the financial sector for credit. 
Specifically the chapter finds which channel is more effective and more responsible for the spread and growth of financial development in countries and shows that financial linkages are the most effective channel followed by trade and geography respectively. This means that for poor countries to attain the minimum requirement level of financial development needed for growth convergence financial linkages will play very crucial role.

Chapter 4 investigates why Africa has not experienced contagion in the area of a lingua franca (a common language used by speakers of different languages). Specifically it finds the limitations to contagion in lingua franca in Africa posing the question whether ethno- linguistic fractionalization and linguistic fractionalization are contagious and are perpetuated in Africa. It attempts to answer why, unlike other countries and continents, no single language has spread through the whole region of Africa. Further, the chapter finds possible explanations for the situation of Africa and makes some policy recommendations based on the findings of the chapter. 


\section{Chapter 2}

\section{Currency Crises and Exchange Market Pressure - Contagion, Trade and Geography}

\subsection{Introduction}

Contagion in currency crises has received much attention both theoretically and empirically. This follows the increasing regional experience of currency crises around the world. For example, the Russian Crisis of 1998 followed the Asian Crisis of 1997, which started with an attack on the Thailand baht and spread to South Korea, Indonesia, Malaysia and the Philippines. Also the Mexican Crisis of 1994 was followed by the Latin America Tequila Crisis associated with speculative attacks in countries including Argentina, Venezuela, Peru, Brazil, Thailand, Hong Kong, Hungary, and the Philippines.

Economic contagion can be defined in different ways including the following as stated by Edwards (2000): (1) global disturbances that affect most countries in the world; (2) shocks coming from a related country; (3) a situation where the extent and magnitude of the international transmission of shocks exceeds what was expected by market participants. The first and second definitions are the ones considered for discussing contagion in this chapter.

Chiodo and Owyang (2002) define a currency crisis as a speculative attack on a country’s currency brought about by agents attempting to alter their portfolio by buying another currency with the currency of the domestic country. There are three generations of currency crises. Krugman (1979), Flood and Garber (1984) and Dooley (1997) developed the first generation models; Obstfeld (1994) developed the second generation models, and Krugman (1999) and Aghion, Bacchetta, and Banerjee (2000) developed the third generation models. Chiodo and Owyang (2002) discovered four factors, namely domestic debt, pegged exchange rate, expectations, and the state of financial markets, that cause and exacerbate currency crises. 
Pesenti and Tille (2000) also discuss some generations of currency crises and related them to the Asian crises. In addition to what previous studies say about the first generations model they state that even if a country does not run large fiscal deficits it can still experience currency crises when financial difficulties necessitate government bailouts. They also explain that chronic current account deficits make countries more vulnerable because of dependency on foreign capital. Relating to the Asian crises, Hong Kong, Taiwan and Singapore had low debts and current account surpluses as opposed to Thailand, Malaysia and Indonesia and South Korea, who had huge current account deficits in the 1990's.

The second generation model explains that geographic neighbors, trade partners and the world's financial markets are responsible for the spread of currency crises. Pesenti and Tille (2000) explain that when foreign investors expect devaluations, they will ask a high premium which increases borrowing cost and limits credit opportunities and governments abandon the peg. The third generation model explains that because the banks and the financial markets are fragile, increases in interest rates make firms' default rate high, and this becomes a lending constraint. Kaminsky and Reinhart (1996) explain the twin problem between the banking sector and currency crises.

The contribution of this chapter is that it attempts to measure trade and geographic channels of currency crises transmission separately as well as examine the effects of economic fundamentals on currency crises (the extent to which economic fundamentals aggravate currency crises in a country). Edwards (2000) employ VAR to investigate volatility contagion while Eichengreen, Rose and Wyplosz (1996) and Glick and Rose (1999) employ probit models to address contagion in currency crises. This is the first study that uses a spatial econometric model to study contagion in currency crises. This model has the advantage of accounting for multi- 
directional effects as opposed to unidirectional effects captured in the conventional econometrics models. In addition, it is also convenient for situations where spatial dependence exists in the data.

This chapter produces evidence supporting the existing hypothesis that trade is contagious in transmitting currency crises and or exchange market pressure from one country to the other and that it does so to a larger extent than existing findings. Second, this chapter also examines whether contagion is only crises phenomenon. It shows that there is contagion during strong and stable currency periods, the impact through trade and geographic linkages is positive and that trade linkages have a larger magnitude in this case than during currency crises. For geography, the magnitude is same as during currency crises.

Also, this chapter examines whether macroeconomic channels are economically significant in explaining currency crises or exchange market pressure. The findings suggest that trade has been the dominant factor to which geography is next. These two channels explain why during currency crises, some countries are infected while some are not. For example, it explains why during the Asian Crisis in 1997-98 countries like Russia and some Asian countries lay pray to the endemic crisis, but countries like Taiwan, Hong Kong and Singapore were not infected even though they are in the same region. Or, why the Tequila Crisis in Latin America during 1994-95 infected other Latin American countries and Hungary but did not affect Chile?

This chapter poses the question, given that a country experiences currency crises or some level of exchange market pressure, what percentage of it is attributable to trade channels or geographic channels? 
In section 2, I present some theoretical explanations of the transmission mechanisms; present my methodology in section 3 followed by my results and interpretation in section 4 and conclusion in section 5 .

\subsection{Channels of Transmission}

While all the three generations of currency crises agree on financial markets as a channel of transmission and have also spelt out the macro-economic fundamentals that matter in explaining currency crises, the second generation models of currency crises identify trade and geography in particular as contagious channels. This chapter therefore explains three channels of contagion namely geography, trade and financial markets.

\subsubsection{Geography}

Chiodo and Owyang (2002) pointed out some channels of transmission of currency crises including common events affecting geographic neighbors. These events include wars or oil price shocks or other events common to a geographical location that could affect the exchange markets of countries located in that area. For example, when there is war in one or two West African countries, this may lead not only to speculative attack on the currencies of the countries involved but on the currencies of neighboring countries as well.

Moreover, countries in the same region tend to belong to economic unions and may be easily infected by events from a member country. For example, Kaminsky and Reinhart (2000) documented that if Mexico devalues and a diversified investor sells his equity and bond holdings, he may do the same with respect to Argentina. This could be classified as a geographic channel since it originates from the effect of a common factor (lender in this case) on that region. 


\subsubsection{Trade}

Another channel identified as a transmission mechanism of currency crises is trade. This trade linkage may hold even if the countries involved do not engage in bilateral trade. Kaminsky and Reinhart (2000), for example, proved that bilateral trade in itself has not been a major force behind recent crises. They gave an example of the Asian Crisis, in which the bilateral trade between the countries involved was relatively very small, to prove this. This finding, notwithstanding, does not overrule the fact that bilateral trade may magnify the spread of currency crises. This will happen when a trade partner devalues its currency and competition for exports necessitates the other to do the same.

The most widely accepted trade channel is the competition for exports in a third country's market by other countries. If one of these countries devalues, it is most likely to cause the others to do the same. Kaminsky and Reinhart (2000), however, showed that it is not always so unless the competitors are all exporting same products to this third market. A more general way to see this will be a competition for exports (of all export goods produced by each country) in a global market. Devaluation in some countries can increase their export or export growth and cause countries that produce similar exports to devalue as well. With increasing globalization, the effect of a global market may even be more pronounced as this covers competition for all export goods and services. What is necessary here is same or similar export goods for the countries involved.

Thus this trade linkage may work if there is a high bilateral trade between two countries, one of which is experiencing a crisis, and or a competition (for exports) between countries hit by currency crises and other countries in a third-party market (in this study global market) or both trade forms. 


\subsubsection{Financial Markets}

Kaminsky and Reinhart (2000) examined two financial market channels. First, a common bank creditor which serves as a regional block to other countries can transmit currency crises. This is linked with trade as countries which engage in trade need strong financial market interconnections and facilities. When this common creditor country is faced with huge nonperforming loans in one country it may lend less in that country as well as the other customer countries.

The second financial market channel has to do with mutual funds and cross-market hedging in which globally diversified investors decide to sell their bond and equity holding of one country as the other country (related by geography or some other common characteristic) devalues its currency. For example, Baig and Ilan (1999) found evidence of cross-border contagion in currency and equity markets.

Empirical investigation of this channel has posed a problem: mutual fund and cross hedging were not in existence until the 90's. To address this, the chapter uses the trade channel as a proxy for the financial markets channel. By national income accounting identities, trade flows are equivalent to capital flows. In other words, trade in goods and services are equivalent to trade in financial assets. Thus based on this identity, both channels should produce same results.

\subsection{Methodology}

\subsubsection{Model}

This study uses spatial autoregressive model (SAR) and spatial error model (SEM). SAR specifies a country's currency crisis as a function of the weighted value of the currency crises of 
it neighbors. SEM models the error term of a country's currency crisis as a function of the weighted value of its geographic neighbors' currency crises. These are similar to the time series ARMA and MA models except that they use distance lags rather than time lags. Anselin (1988), Anselin and Moreno (2003) as well as LeSage and Pace (2004) explain these models extensively.

To use the above approach, I first test for the presence of spatial dependence using the Lagrangian Multiplier (LM) test which shows whether OLS estimates would be biased and also helps chose the best spatial model (the one with the largest LM t-statistic) that can remove the unobserved spatial dependence. I used both models in my analysis, but based on my tests, SEM is best suited for all the regression even though the results for SAR are very close. I will provide my results based on both.

These models are specified below:

SAR:

$$
Y_{t}=\alpha+\rho W Y_{t}+\beta X_{t}+v_{t}
$$

SEM :

$$
Y_{t}=\alpha+\beta X_{t}+\varepsilon_{t} ; \quad \varepsilon_{t}=\lambda W \varepsilon_{t}+\eta_{t}
$$

Or, for regressions that use lagged dependent variables,

$$
Y_{t}=\alpha+\beta X_{t}+\omega Y_{t-1}+\varepsilon_{t} ; \quad \varepsilon_{t}=\lambda W \varepsilon_{t}+\eta_{t}
$$

where $W$ is an NXN weight matrix with respect trade or geography; $X_{t}$ is a vector of controls variables, $Y_{t}$ is an NX1 vector of measures of the dependent variables, $\rho$ and $\lambda$ are the spatial autoregressive and spatial error coefficients respectively (which represent the percentage of a country's dependent variable accounted for by the dependent variable of its trade linkages or geographic neighbors), and $v_{t}$ and $\varepsilon_{t}$ are NX1 matrixes of iid random errors. 
All of these models are run in MATLAB.

\subsubsection{Measuring the Dependent Variables}

My index of exchange market pressure (EMP), used to compute my dependent variables, is constructed as a weighted average of reserve changes and exchange rate changes similar to the way it is constructed in Kaminsky and Reinhart (1996). I construct my index of EMP as below:

$E M P_{i t}=\left[\theta\left(\% \Delta e_{i t}\right)-\delta\left(\% \Delta r_{i t}-\% \Delta r_{G i t}\right)\right]$

where $e_{i t}$ represents the price of a DM in country $i$ 's currency at time t; $r_{i t}$ is country $i$ 's

international reserves, $r_{\text {Git }}$ is German international reserves and $\theta$ and $\delta$ are weights. My choice of Germany as the center country follows the reasoning used in Eichengreen, Rose and Wyplosz (1996); the currency of Germany had been strong throughout the post war era.

Based on the above I construct different measures of currency crisis and currency stability. The conventional method is to find a benchmark EMP value and assign the currency crisis a dummy when a country's EMP in a particular year exceeds this threshold EMP. I used this index also in my analysis to help me compare my results with similar papers. Below is how this dummy is defined:

$$
\text { Crisis }_{\uparrow, t}=\left\{\begin{array}{cc}
1 & \text { if } E M P_{i t}>1.5 \sigma_{E M P}+\mu_{E M P} \\
0 & \text { otherwise }
\end{array}\right.
$$


where, $\mu_{E M P}$ is the sample mean and $\sigma_{E M P}$ is the sample standard deviation. One limitation I realized with this index is that it does not tell much about the severity of the crisis, since it gives the same value to all countries experiencing high EMP's. This can either overvalue or undervalue the magnitude of the spread of currency crises. To make up for this, I expressed currency crises in two ways: one as the actual excess EMP over the threshold and the other as the excess as a percentage of the threshold as shown in equation 3 and 4 respectively. For EMP's equal to or less than the threshold, the crises index is zero since that is an indication of low exchange market pressure or stability.

$$
\begin{aligned}
& \text { Cisis }_{i t}=E M P_{i t}-\left(1.5 \sigma_{E M P}+\mu_{E M P}\right) \\
& \text { Cisis } s_{i t}=\frac{\left[E M P_{i t}-\left(1.5 \sigma_{E M P}+\mu_{E M P}\right)\right]}{\left(1.5 \sigma_{E M P}+\mu_{E M P}\right)} * 100
\end{aligned}
$$

Using just the excess EMP or equation (6) has not changed my results much, but I decide to maintain the definition based on equation (7) above because it rationalizes the currency crisis index both across years and across countries as each index is not just a deviation from the threshold but also the percentage deviation from the threshold. Only years with currency crises of five or more, based on this measure, were studied. This is because Eichengreen, Rose and Wyplosz (1996) found that contagion is not likely to take effect when just one or a few speculative attacks have occurred. My crisis years are thus, 2003, 2001, 1998, 1992, 1990, 1988 and 1987. For simplicity and comparison I used same years for regressions using other dependent variables in this study. 
I also construct a currency stability index as another dependent variable in addition to exchange market pressure and currency crises. For every country for which the excess EMP over the threshold is negative, I interpret it as a stable and strong currency. Since the closer an EMP is to the threshold means it is closer to crisis than a stability, larger negative deviations mean a more stable and stronger currency than smaller negative deviations. As a result I used the same measure as above but took the absolute value. For example, two countries with excess EMP as a percentage of the threshold as -5 and -10 will now have stability measures as 5 and 10 respectively. For EMP equal to or greater than the threshold, the stability index is zero since that is an indication of high exchange market pressure or crises. In similar notation as above,

Stability $_{i t}=\left|E M P_{i t}-\left(1.5 \sigma_{E M P}+\mu_{E M P}\right)\right|$

Stability $=\left|\frac{\left[E M P_{i t}-\left(1.5 \sigma_{E M P}+\mu_{E M P}\right]\right.}{\left(1.5 \sigma_{E M P}+\mu_{E M P}\right)} * 100\right|$

\subsubsection{Constructing the Weight Matrices}

The weight matrix for the geographic channel is based on first order contiguity. A country will only give a positive weight to another country if it is its neighbor, otherwise a zero weight. The spatial weight given by a country to its neighbor is expressed as the inverse of the total number of neighbors the country has based on first-order contiguity (usually referred to as the "queen case" in spatial econometrics). The weights are row-standardized for each of the countries so that each country's total weight given equals 1 . This is represented in matrix notations below: 


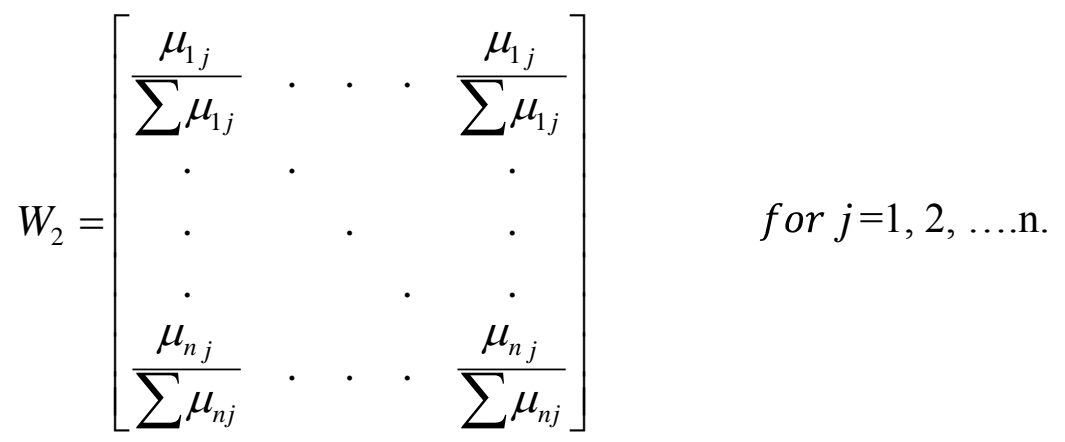

where $\mu_{i j}=\left\{\begin{array}{cc}1 & \text { if country } i \text { and jareneighbors } \\ 0 & \text { otherwise }\end{array}\right.$

The trade weight matrix must capture the theoretical explanation of trade linkages. This should reflect competition for exports between countries that engage in bilateral trade and or competition of countries for exports in third country's market or the global market. The idea is that if any of these competitors suffers from currency crises (or has a strong currency), it can easily spillover to other competitors. As a result, my first trade weight matrix uses bilateral export between countries as in Leeson and Sobel (2006). In this case, country A gives a weight equal to the ratio of his export to each country to its total exports. In matrix form,

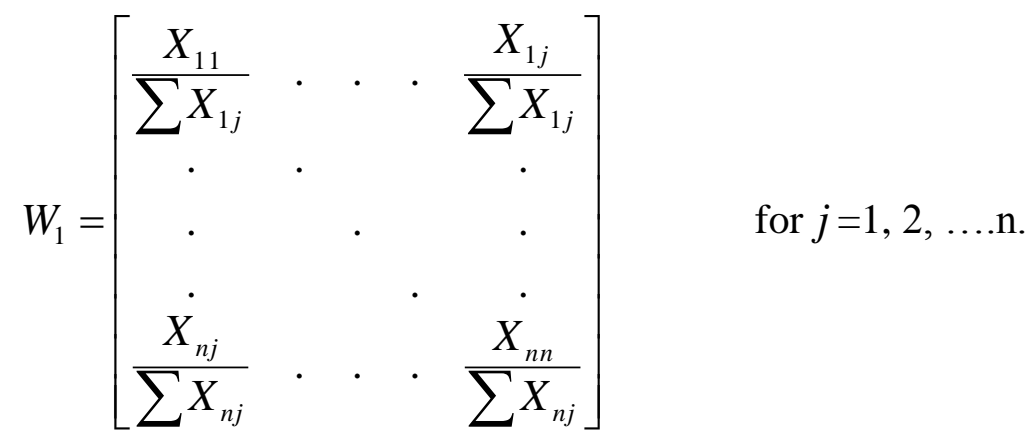

where $X_{i, j}$ is country $i$ 's export to country $j$. Since a country cannot send exports to itself, the principal diagonal is zero. 
The above matrix is however not enough to capture the trade weight since countries which do not engage in bilateral trade may still be infected by currency crises in non-trade partner countries. I therefore construct another weight matrix in which a country would assign a weight to other countries based on the magnitude and growth rate differential of their export shares of GDP and merged it with the above.

For this weight matrix, country $i$ finds the difference between its export share of GDP or growth rate of export share of GDP and gives a weight directly corresponding to this difference to all countries for which this value is positive. Otherwise, country $i$ gives a weight corresponding to the inverse of the absolute value of this value. This is represented in matrix notation below:

$$
W_{2}=\left[\begin{array}{ccccc}
\frac{X_{1}-X_{1}}{\sum\left(X_{i}-X_{1}\right)} & \frac{X_{2}-X_{1}}{\sum\left(X_{i}-X_{1}\right)} & & & \frac{X_{n}-X_{1}}{\sum\left(X_{i}-X_{1}\right)} \\
\frac{X_{1}-X_{2}}{\sum\left(X_{i}-X_{2}\right)} & \frac{X_{2}-X_{2}}{\sum\left(X_{i}-X_{2}\right)} & & \cdot & \frac{X_{n}-X_{2}}{\sum\left(X_{i}-X_{2}\right)} \\
\cdot & \cdot & \cdot \\
\cdot & \cdot & \cdot & \\
\frac{X_{1}-X_{n}}{\sum\left(X_{i}-X_{n}\right)} & \frac{X_{2}-X_{n}}{\sum\left(X_{i}-X_{n}\right)} & & \cdot & \frac{X_{n}-X_{n}}{\sum\left(X_{i}-X_{n}\right)}
\end{array}\right] \text { for } i=1,2 . . n
$$

where $X_{i}$ can either be interpreted as a country's export share of GDP or the growth rate of the country's export share of GDP. Exports shares account for the size of countries economy which is important in determining competition for exports between countries.

Let $X_{i}-X_{j}=d_{i j}$, so that $X_{1}-X_{1}=d_{11}$ and $\sum\left(X_{i}-X_{j}\right)=\sum d_{i j}$

Then for 


$$
\begin{aligned}
& X_{i}-X_{j} \geq 0 \\
& d_{i j}=X_{i}-X_{j}
\end{aligned}
$$

And for

$$
\begin{aligned}
& X_{i}-X_{j}<0 \\
& d_{i j}=\left|X_{i}-X_{j}\right|^{-1} ; X_{i} \neq X_{j}
\end{aligned}
$$

Thus this weight matrix rules out the possibility of two countries having exactly the same export share of GDP. It is only on the principal diagonal that we must have zeroes since each country's exports share of GDP deviation with respect to itself is zero $\left(d_{i i}=0\right)$. This simplifies the above weight matrix to:

$$
W_{2}=\left[\begin{array}{ccccc}
\frac{d_{11}}{\sum d_{i 1}} & \frac{d_{21}}{\sum d_{i 1}} & \cdot & \cdot & \frac{d_{n 1}}{\sum d_{i 1}} \\
\frac{d_{12}}{\sum d_{i 2}} & \frac{d_{22}}{\sum d_{i 2}} & \cdot & \cdot & \frac{d_{n 2}}{\sum d_{i 2}} \\
\cdot & \cdot & \cdot & & \cdot \\
\cdot & \cdot & & \cdot & \cdot \\
\frac{d_{1 n}}{\sum d_{i n}} & \frac{d_{2 n}}{\sum d_{i n}} & \cdot & \cdot & \frac{d_{n n}}{\sum d_{i n}}
\end{array}\right]
$$

$$
\text { for } i=1,2, \ldots \mathrm{n}
$$

For all countries country $i$ 's export share of GDP (or growth rate of) is smaller than, it will give them a weight directly related to these deviations. On the other hand for all countries country $i$ 's export share of GDP or growth rate of export share of GDP is higher than, the deviation will be negative and hence country $i$ will give them a weight that equals the inverse of the absolute value of the deviation. This ensures that all countries with positive deviations have higher weights than those with negative deviations with respect to country $i$.

The final trade weight matrix takes the following forms:

1. $W_{2}$, using export share of GDP 
2. $W_{2}$, using growth rate of export share of GDP

3. A linear combination of $W_{2}$ in (1) above with $W_{1}$

4. A linear combination of $W_{2}$ in (2) above with $W_{1}$

This chapter uses all the different combinations above for robustness and also tests $W_{1}$ to see if bilateral trade alone is a sufficient trade channel for contagion.

\subsubsection{Independent Variables}

In line with the theoretical framework and based on availability of data for the sample chosen, the following control variables are employed. They are mostly domestic fundamentals including the current account as a share of GDP, growth rate of domestic credit, the CPI, real GDP growth rate, money stock (M2) and unemployment rate. The choice of these independent variables is based on the theoretical framework explained earlier. All these variables were included as deviations from German values as it is the center country.

\subsubsection{Data}

The study covers a period of twenty years from 1985 to 2005 . The choice of this period is a result of the bandwagon of currency crises that hit the world in recent years especially the 1990’s. Starting from the European Exchange Rate Mechanism collapse between 1992 and 1993 to the Asian crisis and the Russian default in 1998, there are many cases to consider within the period under study. A panel of 119 countries is chosen for this study.

Data is taken from different sources including the World Bank Databases (World Development Indicator), the IMF databases (IFS and DOS) and the World Fact Book. Detailed description of the data is in Appendix 1. 


\subsection{Results}

My results confirm the existing theoretical framework suggesting that trade and geography are the transmission mechanisms of currency crises. The findings also support the hypothesis that trade is the most dominant channel of contagion in currency crises. Furthermore, my results suggest that currency stabilities in countries can also propagate to other countries through the same trade links in a higher magnitude than does currency crises. The magnitude of the spread through geography though is the same for currency crises and currency stabilities in this study.

Exchange Market Pressure (EMP) is also found to be contagious through geography and trade links. I present my results in Table 1.1 - Table 1.6 (Table 1.4 and Table 1.5 provide results for robustness checks using different dependent variables). Though I run the regression for both models, based on my LM test SEM results are best for this analysis except for the dummy dependent variables which uses SAR.

The results suggest that country's catch 0.24 of their EMP from their geographic neighbors. This is shown as lambda in Table 1.1, column 3, and it is significant at $1 \%$. The trade channel nevertheless is of a much higher magnitude; 0.35. This is also found in column 6 (column 7 reports similar result using a different weight matrix for robustness checks) of Table 1.1. The lagged level of EMP is not significant in all of the regressions, meaning that exchange market pressure can produce surprising shocks. A country with a low EMP the previous period can suddenly have a high EMP in the current period.

Table 1.2 presents the results for currency crisis. The study shows that countries catch 0.15 of their currency crisis from geographic neighbors (shown as lambda in column 3). For trade, this coefficient is between 0.14-0.17 depending on the trade weight matrix used (shown as lambda in column 6 and 7). This means that trade linkages are more important than geographic 
measures in explaining contagion in currency crises. The measure of currency crisis used here was based on equation (4). The results for a similar measure, based on equation (3) are also reported in Table 1. 4 for robustness checks.

The results for the measures of currency stability are quite interesting. Lambda is larger for both trade and geography regressions than it is for the measures of currency crisis. Table 1.3 presents the results of currency stability. For both measures of currency stability, lambda for the geography regression is 0.17 . This is found in column 3 of Table 1.3 and Table 1.5. It implies that countries catch 0.17 of the strength of the currency of their geographic neighbors. For the trade regression, lambda is between 0.45-0.49 using the measure based on equation (5). This can be found in column 6 and 7 of Table 1.3. The results for a similar measure, based on equation (5), are also reported in Table 1.5 for robustness checks.

Also, the result for the geographic channel and its lower magnitude than the trade channel is intuitive; when the trade effect becomes very large it can be enough to spread currency crises regardless of distance (for example the Russian default linked to the Asian Crisis and the Tequila Crisis infecting Hungary), but the combination of the geography effect and the trade effect produces a synergy that makes currency crises regional. That geographic channel alone is less strong and perhaps not enough could help answer questions like why during the Asian Crisis countries like Taiwan, Singapore and Malaysia were not infected or why during the Tequila Crisis Chile was not infected. Sometimes the trade effect between two distant countries could be bigger than the amalgamation of the trade and geography effects for two neighbors though the opposite is more prevalent as in current episodes.

All results are robust using different measures of dependent variables as well as different weight matrices for trade. The regression is also run for each of the years chosen for the study 
and results for 1998, for example, are as follows: geography is accountable for 0.19 of a currency crisis, 0.14 of currency stability, and 0.17 of an exchange market pressure while trade is accountable for 0.35 of currency stability. All these results are significant at 5\%,10\%, 5\%, and $1 \%$ respectively.

However compared to former studies, especially Eichengreen, Rose and Wyplosz (1996), who studied currency crises, trade linkages and macroeconomic channels, my results differ significantly using my measure of currency crisis but similar to theirs when dummy variables are used as in those studies. Table 1.6 shows the result when dummy variables were used for the measures based on equation (2). Rho, shown in column 4 is 0.053 for currency crisis which is close to the 0.08 produced by Eichengreen, Rose and Wyplosz (1996). Second, using this measure of currency crisis confirms my results above even though rho is just higher for this new measure. The results in Table 1.4 show that countries catch 0.07 of the currency crisis of their geographic neighbors and 0.13 of the currency stability of their geographic neighbors. The results are 0.053 and 0.31 respectively by trade partners and trade competitors. These are shown as rho in columns $2,3,4$, and 5 respectively.

Comparing the trade linkages for currency crises and currency stabilities it is obvious that the later is of a higher magnitude than the former; almost three times larger ( 0.49 against 0.17$)$. An obvious reason why the magnitude of the contagion is so high for the currency stability measure is that for countries trading with each other or competing in a third market for exports, one cannot decide to consistently devalue its currency when the currency of the others are strong due to the fear of potential retaliation and or a direct pressure exerted by these trading competitors to allow its currency to appreciate for a fair competition. For example, China receives increasing pressure from the U.S. in the form of calls for import barriers to allow the 
yuan to appreciate as explained by Bown, Crowley, McCulloch, and Nakajima (2005). Currency crises, on the other hand, spread by indirect competition and have lower magnitude than the former.

Moreover, I have examined if bilateral trade alone is sufficient for contagion and found no such evidence. By using the bilateral trade weight matrix alone, no lambda in all regressions is significant. This finding is consistent with the claim of Kaminsky and Reinhart (2000) that bilateral trade has not been a force behind recent crises. Lambda is significant when the weight matrices based on competition in a third-party market (global market) are used and most times higher when this weight is combined with the bilateral trade weight. This means that bilateral trade is neither necessary nor sufficient for contagion but can increase its magnitude.

This chapter does not investigate into how macroeconomic variables spread currency crises but used them as control variables to find out how they can affect a country's own currency crisis. For all of my macroeconomic variables controlled for, apart from unemployment (the coefficient of unemployment was $6 \%$ in all regressions in Table 1.1 , but became $1 \%$ in Table 1.6 when dummy dependent variables are used), this chapter found some statistically but not economically significant as found by Eichengreen, Rose and Wyplosz (1996).

On the other hand, the divergence in magnitude of my trade results from those by Eichengreen, Rose and Wyplosz (1996) and other empirical studies may largely be because my crisis measures account, not only for the existence of currency crisis but, also for its relative intensity as opposed to previous studies. Second, my trade weight matrix captures not only exports but also accounts for the size of a country's economy (GDP) as well the growth rate of exports. Furthermore, the spatial econometrics technique used accounts for multi-directional 
effects as opposed to the conventional econometric models and it is also convenient for studying contagion of this kind, where spatial dependence exists in the data.

\subsection{Conclusion}

This chapter attempted to study contagion in currency crises and exchange market pressure by incorporating the geography weight matrix and also introducing a new dependent variable, currency stabilities, to the already existing empirical work. The results both confirm and improve upon the former studies in this area of study.

The chapter suggests that geographic measures are also very significant and are captured by certain unmeasured common shocks that are identified only with countries in a certain geographical location. It also explains that while the summation of geographic and trade channels of currency crises are responsible for the contagion in certain regions (which accounts for why larger percentage of the infection is regional), the high magnitude of the trade channel accounts for the spread of currency crises to other trade competitors outside the geographic location of the initial attack.

Second, though trade spreads currency crises, the positive effect it has during periods of currency stabilities are much larger (about three times more) than the adverse effects during crises. This may imply that the overall global effect of the trade linkages is not a zero sum or decreasing sum game but an increasing sum game.

For policy recommendation, this would suggest that trade should be encouraged as countries come to learn this findings. For geography, since countries cannot choose their neighbors, the only thing to do is to realize that what happens in the exchange market "next door" can affect you and hence the need to be prepared for it. One way to do this is to encourage 
strong economic unions that could help deal with such common adverse or favorable events as well as other unmeasured common shocks that hit the currency markets of regions around the world. 
Table 1.1. Contagion- Exchange Market Pressure

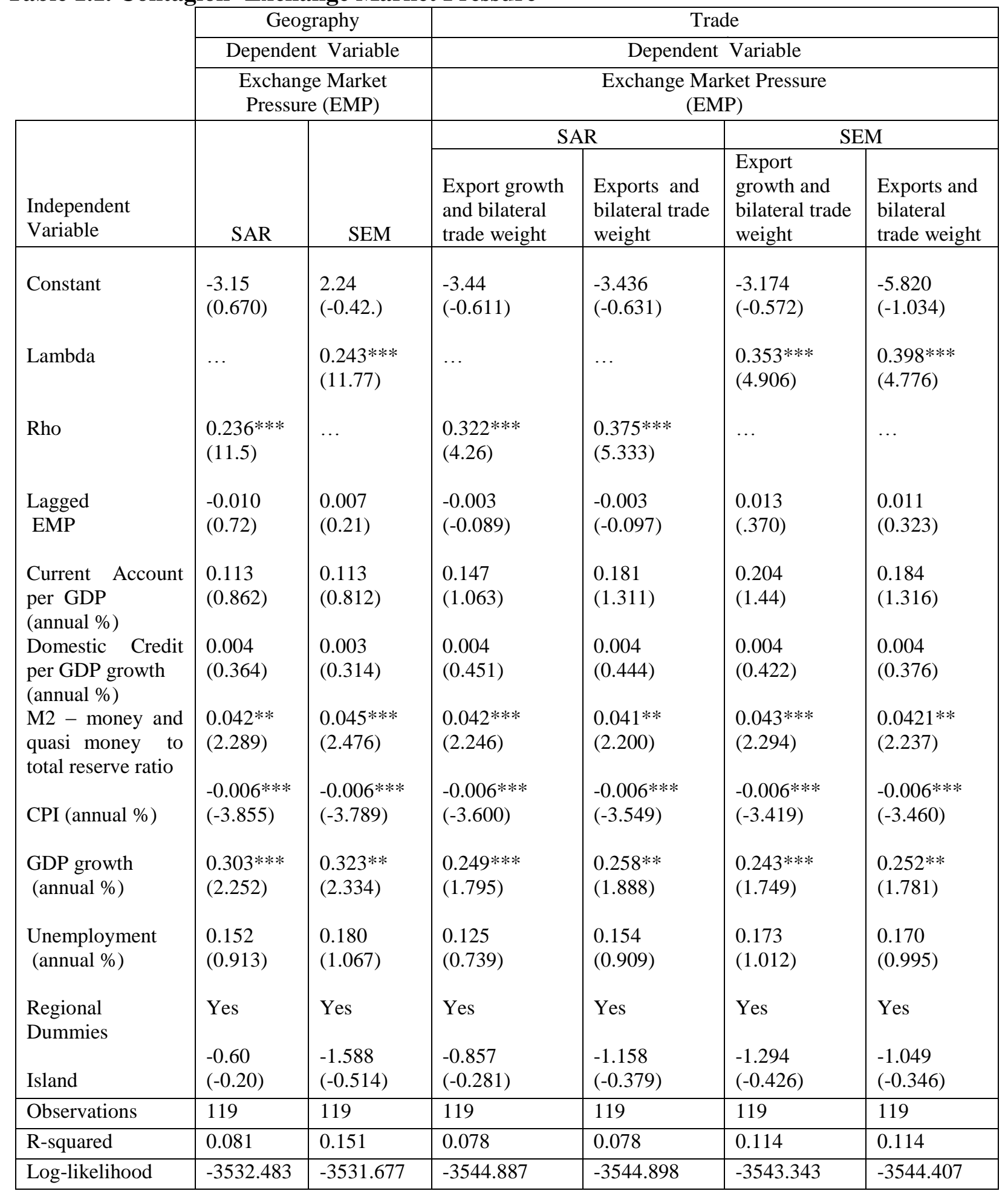

Notes: t-statistics in parentheses; asterisks indicate significance as follows: $* * *=1 \%, * *=5 \%, *=10 \%$. Variable description, descriptive statistics, and sources can be found in Appendix 1. 
Table 1.2. Contagion- Currency Crisis

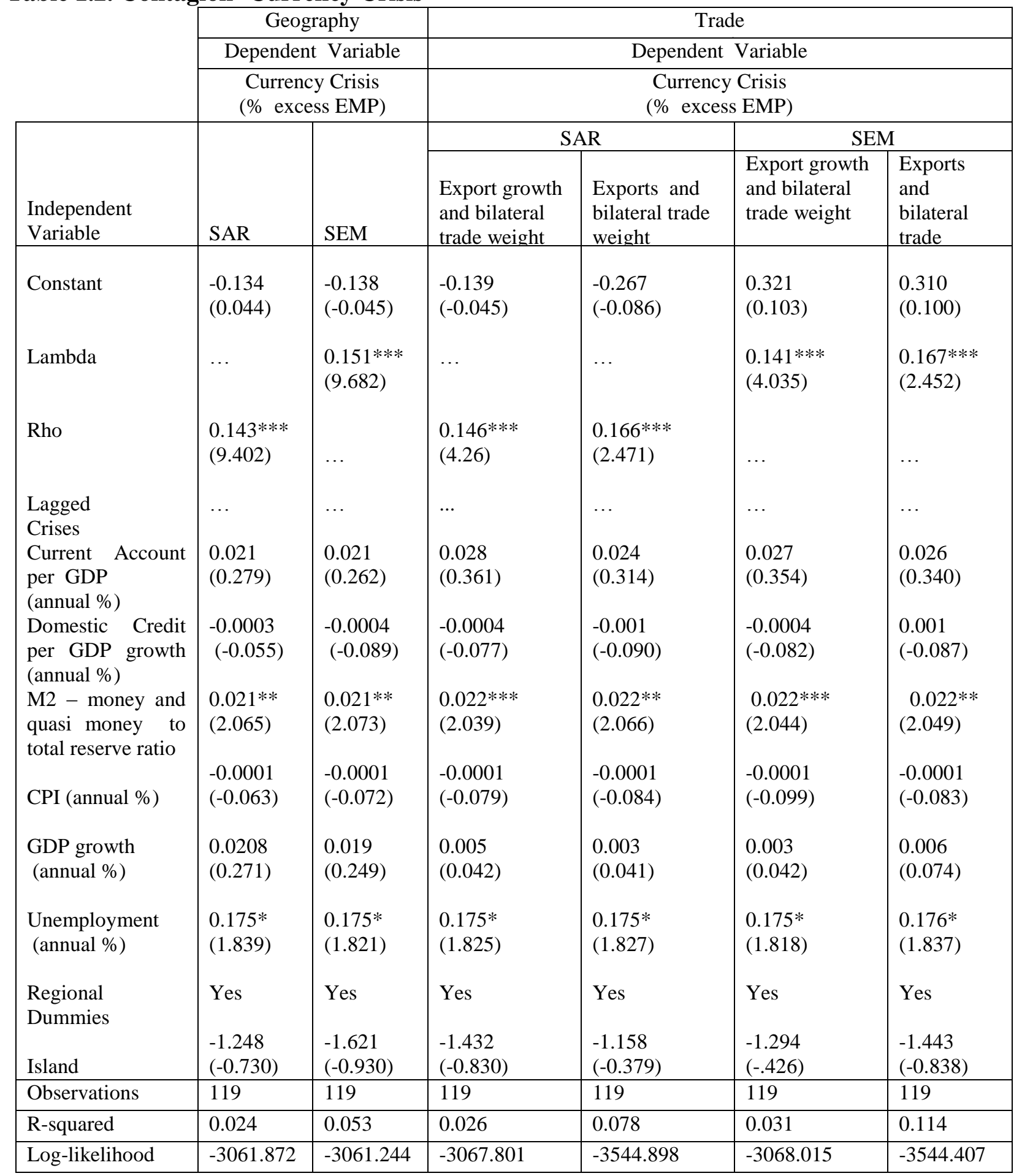

Notes: t-statistics in parentheses; asterisks indicate significance as follows: $* * *=1 \%, * *=5 \%, *=10 \%$. Variable description, descriptive statistics, and sources can be found in Appendix 1. 
Table 1.3. Contagion- Currency Stability

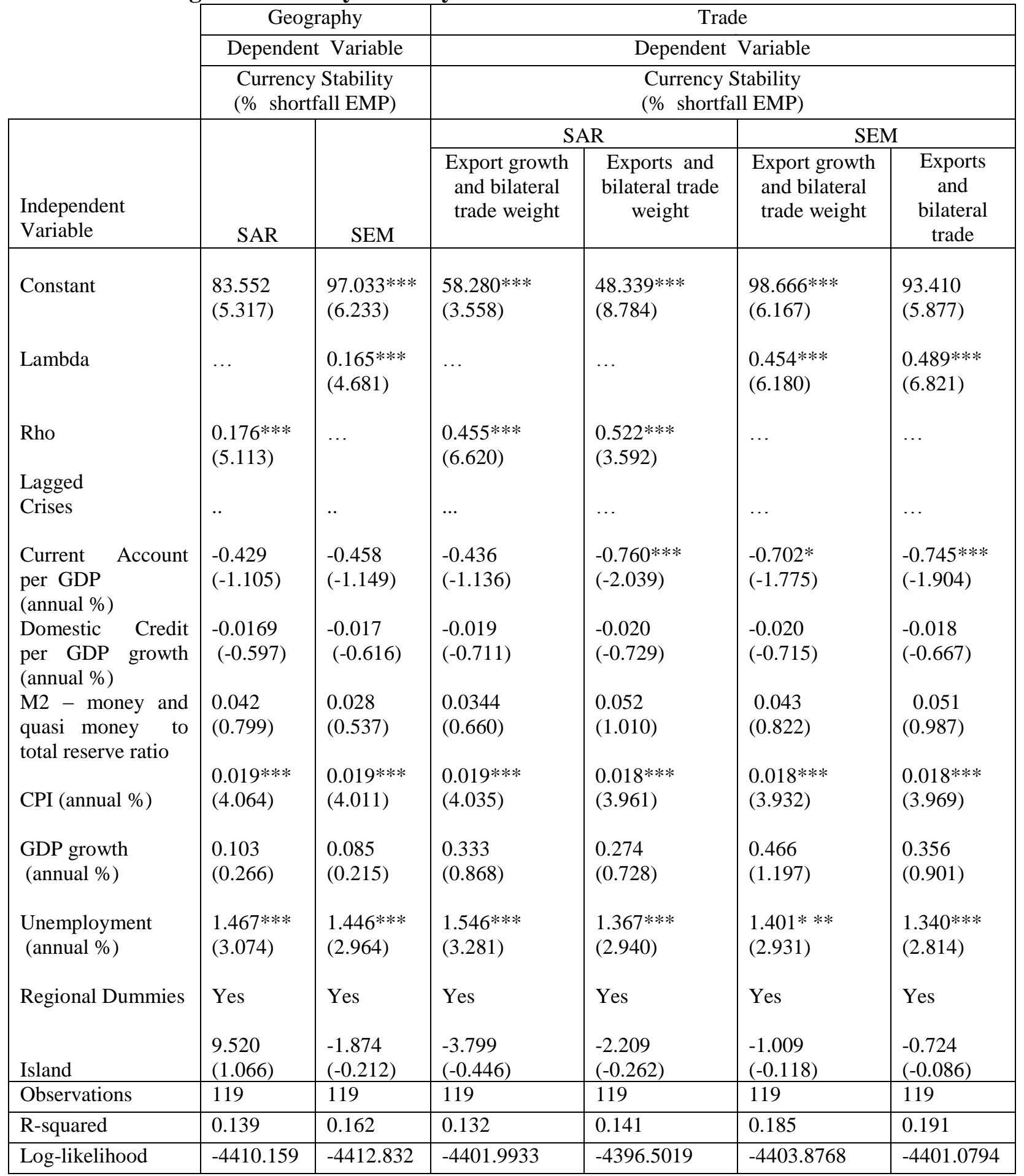

Notes: t-statistics in parentheses; asterisks indicate significance as follows: $* * *=1 \%, * *=5 \%, *=10 \%$. Variable description, descriptive statistics, and sources can be found in Appendix 1. 
Table 1.4. Contagion- Currency Crisis (robust)

\begin{tabular}{|c|c|c|c|c|c|c|}
\hline \multirow[b]{5}{*}{$\begin{array}{l}\text { Independent } \\
\text { Variable }\end{array}$} & \multicolumn{2}{|c|}{ Geography } & \multicolumn{4}{|c|}{ Trade } \\
\hline & \multirow{2}{*}{\multicolumn{2}{|c|}{$\begin{array}{c}\text { Dependent Variable } \\
\text { Currency Crisis } \\
\text { ( excess EMP) }\end{array}$}} & \multicolumn{4}{|c|}{ Dependent Variable } \\
\hline & & & & $\begin{array}{c}\text { Currency } \\
\text { (excess }\end{array}$ & $\begin{array}{l}\text { Crisis } \\
\text { EMP) }\end{array}$ & \\
\hline & \multirow[b]{2}{*}{ SAR } & \multirow[b]{2}{*}{ SEM } & \multicolumn{2}{|c|}{ SAR } & \multicolumn{2}{|c|}{ SEM } \\
\hline & & & $\begin{array}{l}\text { Export growth } \\
\text { and bilateral } \\
\text { trade weight }\end{array}$ & $\begin{array}{c}\text { Exports and } \\
\text { bilateral trade } \\
\text { weight } \\
\end{array}$ & $\begin{array}{l}\text { Export growth } \\
\text { and bilateral } \\
\text { trade weight }\end{array}$ & $\begin{array}{l}\text { Exports } \\
\text { and } \\
\text { bilateral } \\
\text { trade } \\
\end{array}$ \\
\hline Constant & $\begin{array}{l}-0.012 \\
(-0.012)\end{array}$ & $\begin{array}{l}-0.002 \\
(-0.001)\end{array}$ & $\begin{array}{l}-0.008 \\
(-0.008)\end{array}$ & $\begin{array}{l}-0.030 \\
(-0.029)\end{array}$ & $\begin{array}{l}0.147 \\
(0.141)\end{array}$ & $\begin{array}{l}0.170 \\
(0.163)\end{array}$ \\
\hline Lambda & $\ldots$ & $\begin{array}{l}0.189 * * * \\
(10.571)\end{array}$ & $\ldots$ & $\ldots$ & $\begin{array}{l}0.144 * * * \\
(4.075)\end{array}$ & $\begin{array}{l}0.170 * * * \\
(2.532)\end{array}$ \\
\hline Rho & $\begin{array}{l}0.174 * * * \\
(4.934)\end{array}$ & $\ldots$ & $\begin{array}{l}0.147 * * * \\
(4.064)\end{array}$ & $\begin{array}{l}0.174 * * * \\
(2.611)\end{array}$ & $\ldots$ & $\cdots$ \\
\hline $\begin{array}{l}\text { Lagged } \\
\text { Crises }\end{array}$ & $\ldots$ & $\ldots$ & $\ldots$ & $\ldots$ & $\ldots$ & $\ldots$ \\
\hline $\begin{array}{l}\text { Current Account } \\
\text { per GDP } \\
\text { (annual \%) }\end{array}$ & $\begin{array}{l}0.010 \\
(0.387)\end{array}$ & $\begin{array}{l}0.010 \\
(0.380)\end{array}$ & $\begin{array}{l}0.012 \\
(0.467)\end{array}$ & $\begin{array}{l}0.011 \\
(0.467)\end{array}$ & $\begin{array}{l}-0.0001 \\
(-0.075)\end{array}$ & $\begin{array}{l}0.012 \\
(0.436)\end{array}$ \\
\hline $\begin{array}{l}\text { Domestic Credit } \\
\text { per GDP growth } \\
\text { (annual \%) }\end{array}$ & $\begin{array}{c}-0.0001 \\
(-0.048)\end{array}$ & $\begin{array}{l}-0.0001 \\
(-0.087)\end{array}$ & $\begin{array}{l}-0.0001 \\
(-0.069)\end{array}$ & $\begin{array}{l}-0.0002 \\
(-0.084)\end{array}$ & $\begin{array}{l}-0.0001 \\
(-0.075)\end{array}$ & $\begin{array}{l}-0.0001 \\
(-0.079)\end{array}$ \\
\hline $\begin{array}{l}\text { M2 - money and } \\
\text { quasi money to } \\
\text { total reserve ratio }\end{array}$ & $\begin{array}{l}0.009 * * * \\
(2.541)\end{array}$ & $\begin{array}{l}0.009 * * * \\
(2.554)\end{array}$ & $\begin{array}{l}0.009 * * * \\
(2.502)\end{array}$ & $\begin{array}{l}0.009 * * \\
(2.526)\end{array}$ & $\begin{array}{l}0.009 * * * \\
(2.503)\end{array}$ & $\begin{array}{l}0.009 * * * \\
(2.504)\end{array}$ \\
\hline CPI (annual \%) & $\begin{array}{l}-0.00003 \\
(-0.098)\end{array}$ & $\begin{array}{l}-0.00003 \\
(-0.101)\end{array}$ & $\begin{array}{l}-0.0001 \\
(-0.079)\end{array}$ & $\begin{array}{l}-0.00004 \\
(-0.134)\end{array}$ & $\begin{array}{l}-0.00005 \\
(-0.147)\end{array}$ & $\begin{array}{l}-0.0004 \\
(-0.133)\end{array}$ \\
\hline $\begin{array}{l}\text { GDP growth } \\
\text { (annual \%) }\end{array}$ & $\begin{array}{l}0.001 \\
(0.038)\end{array}$ & $\begin{array}{l}0.001 \\
(0.249)\end{array}$ & $\begin{array}{l}-0.005 \\
(-0.174)\end{array}$ & $\begin{array}{l}-0.006 \\
(-0.218)\end{array}$ & $\begin{array}{l}-0.006 \\
(-0.211)\end{array}$ & $\begin{array}{l}-0.005 \\
(-0.172)\end{array}$ \\
\hline $\begin{array}{l}\text { Unemployment } \\
\text { (annual \%) }\end{array}$ & $\begin{array}{l}0.058^{*} \\
(1.842)\end{array}$ & $\begin{array}{l}0.059 * \\
(1.823)\end{array}$ & $\begin{array}{l}0.058^{*} \\
(1.794)\end{array}$ & $\begin{array}{l}0.058^{*} \\
(1.805)\end{array}$ & $\begin{array}{l}0.057 * \\
(1.784)\end{array}$ & $\begin{array}{l}0.059 * \\
(1.812)\end{array}$ \\
\hline Regional Dummies & Yes & Yes & Yes & Yes & Yes & Yes \\
\hline Island & $\begin{array}{l}-0.501 \\
(-0.873)\end{array}$ & $\begin{array}{l}-0.661 \\
(-1.127)\end{array}$ & $\begin{array}{l}-0.604 \\
(-1.038)\end{array}$ & $\begin{array}{l}-0.600 \\
(-1.033)\end{array}$ & $\begin{array}{l}-0.587 \\
(-1.009)\end{array}$ & $\begin{array}{l}-0.593 \\
(-1.024)\end{array}$ \\
\hline Observations & 119 & 119 & 119 & 119 & 119 & 119 \\
\hline R-squared & 0.024 & 0.066 & 0.026 & 0.025 & 0.031 & 0.035 \\
\hline Log-likelihood & -2152.590 & -2151.780 & -3067.801 & -2160.222 & -3068.015 & -2160.315 \\
\hline
\end{tabular}

Notes: t-statistics in parentheses; asterisks indicate significance as follows: $* * *=1 \%, * *=5 \%, *=10 \%$. Variable description, descriptive statistics, and sources can be found in Appendix 1. 
Table 1.5. Contagion- Currency Stability(robust)

\begin{tabular}{|c|c|c|c|c|c|c|}
\hline \multirow[b]{5}{*}{$\begin{array}{l}\text { Independent } \\
\text { Variable }\end{array}$} & \multicolumn{2}{|c|}{ Geography } & \multicolumn{4}{|c|}{ Trade } \\
\hline & \multirow{2}{*}{\multicolumn{2}{|c|}{$\begin{array}{c}\text { Dependent Variable } \\
\text { Currency Stability } \\
\text { (EMP shortfall) }\end{array}$}} & \multirow{2}{*}{\multicolumn{4}{|c|}{$\begin{array}{c}\text { Dependent Variable } \\
\text { Currency Stability } \\
\text { (EMP shortfall) }\end{array}$}} \\
\hline & & & & & & \\
\hline & \multirow[b]{2}{*}{ SAR } & \multirow[b]{2}{*}{ SEM } & \multicolumn{2}{|c|}{ SAR } & \multicolumn{2}{|c|}{ SEM } \\
\hline & & & $\begin{array}{l}\text { Export growth } \\
\text { and bilateral } \\
\text { trade weight }\end{array}$ & $\begin{array}{c}\text { Exports and } \\
\text { bilateral trade } \\
\text { weight } \\
\end{array}$ & $\begin{array}{l}\text { Export growth } \\
\text { and bilateral } \\
\text { trade weight }\end{array}$ & $\begin{array}{l}\text { Exports } \\
\text { and } \\
\text { bilateral } \\
\text { trade } \\
\end{array}$ \\
\hline Constant & $\begin{array}{l}9.869^{*} \\
(1.806)\end{array}$ & $\begin{array}{l}14.123 * * \\
(2.614)\end{array}$ & $\begin{array}{l}4.244 \\
(0.860)\end{array}$ & $\begin{array}{l}0.396 \\
(0.069)\end{array}$ & $\begin{array}{l}14.820 * * * \\
(2.703)\end{array}$ & $\begin{array}{l}13.619 * * * \\
(2.443)\end{array}$ \\
\hline Lambda & $\cdots$ & $\begin{array}{l}0.165 * * * \\
(4.647)\end{array}$ & $\cdots$ & $\ldots$ & $\begin{array}{l}0.382 * * * \\
(5.167)\end{array}$ & $\begin{array}{l}0.507 * * * \\
(6.738)\end{array}$ \\
\hline Rho & $\begin{array}{l}0.171 \text { *** } \\
(4.935)\end{array}$ & $\ldots$ & $\begin{array}{l}0.384 * * * \\
(4.894)\end{array}$ & $\begin{array}{l}0.508 * * * \\
(6.881)\end{array}$ & $\ldots$ & $\cdots$ \\
\hline Lagged Crises & .. & .. & $\ldots$ & $\ldots$ & $\ldots$ & $\cdots$ \\
\hline $\begin{array}{l}\text { Current Account } \\
\text { per GDP } \\
\text { (annual \%) }\end{array}$ & $\begin{array}{l}-0.184 \\
(1.348)\end{array}$ & $\begin{array}{l}-0.196 \\
(-1.405)\end{array}$ & $\begin{array}{l}-0.175 \\
(-1.29)\end{array}$ & $\begin{array}{l}-0.278^{* *} \\
(-2.069)\end{array}$ & $\begin{array}{l}-0.254^{*} \\
(-1.829)\end{array}$ & $\begin{array}{l}-0.310^{* *} \\
(-2.258)\end{array}$ \\
\hline $\begin{array}{l}\text { Domestic } \\
\text { per GDP } \\
\text { (annual \%) }\end{array}$ & $\begin{array}{l}0.004 \\
(0.419)\end{array}$ & $\begin{array}{l}0.004 \\
(0.401)\end{array}$ & $\begin{array}{l}0.003 \\
(0.298)\end{array}$ & $\begin{array}{l}0.003 \\
(0.324)\end{array}$ & $\begin{array}{l}0.003 \\
(0.282)\end{array}$ & $\begin{array}{l}0.004 \\
(0.360)\end{array}$ \\
\hline $\begin{array}{l}\text { M2 - money and } \\
\text { quasi money to } \\
\text { total reserve ratio }\end{array}$ & $\begin{array}{l}0.035^{*} \\
(1.905)\end{array}$ & $\begin{array}{l}0.032 \\
(.736)\end{array}$ & $\begin{array}{l}0.0301^{*} \\
(1.666)\end{array}$ & $\begin{array}{l}0.037 * * \\
(2.056)\end{array}$ & $\begin{array}{r}0.033^{*} \\
(1.788)\end{array}$ & $\begin{array}{l}0.036^{* *} \\
(1.982)\end{array}$ \\
\hline CPI (annual \%) & $\begin{array}{l}0.019 * * * \\
(4.011)\end{array}$ & $\begin{array}{l}0.003 * \\
(1.724)\end{array}$ & $\begin{array}{l}0.003 \\
(1.57)\end{array}$ & $\begin{array}{l}0.003^{*} \\
(1.780)\end{array}$ & $\begin{array}{l}0.003 * \\
(1.635)\end{array}$ & $\begin{array}{l}0.003^{*} \\
(1.871)\end{array}$ \\
\hline $\begin{array}{l}\text { GDP growth } \\
\text { (annual \%) }\end{array}$ & $\begin{array}{l}0.129 \\
(0.948)\end{array}$ & $\begin{array}{l}0.112 \\
(0.805)\end{array}$ & $\begin{array}{l}0.105 \\
(0.786)\end{array}$ & $\begin{array}{l}0.105 \\
(0.786)\end{array}$ & $\begin{array}{l}0.228^{*} \\
(1.677)\end{array}$ & $\begin{array}{l}0.135 \\
(0.968)\end{array}$ \\
\hline $\begin{array}{l}\text { Unemployment } \\
\text { (annual \%) }\end{array}$ & $\begin{array}{l}0.147 \\
(0.881)\end{array}$ & $\begin{array}{l}0.099 \\
(0.581)\end{array}$ & $\begin{array}{l}0.105 \\
(0.636)\end{array}$ & $\begin{array}{l}0.105 \\
(0.636)\end{array}$ & $\begin{array}{l}0.119 \\
(0.712)\end{array}$ & $\begin{array}{l}0.064 \\
(0.381)\end{array}$ \\
\hline Regional Dummies & Yes & Yes & Yes & Yes & Yes & Yes \\
\hline Island & $\begin{array}{l}0.777 \\
(0.246) \\
\end{array}$ & $\begin{array}{l}-2.852 \\
(-0.920) \\
\end{array}$ & $\begin{array}{l}-3.799 \\
(-0.446) \\
\end{array}$ & $\begin{array}{l}-3.679 \\
(-1.238) \\
\end{array}$ & $\begin{array}{l}-3.716 \\
(-1.240) \\
\end{array}$ & $\begin{array}{l}-3.717 \\
(-1.260) \\
\end{array}$ \\
\hline Observations & 119 & 119 & 119 & 119 & 119 & 119 \\
\hline R-squared & 0.100 & 0.126 & 0.077 & 0.095 & 0.138 & 0.153 \\
\hline Log-likelihood & -3536.582 & -3538.811 & -3532.869 & -3526.800 & --3533.406 & -3528.421 \\
\hline
\end{tabular}

Notes: t-statistics in parentheses; asterisks indicate significance as follows: $* * *=1 \%, * *=5 \%, *=10 \%$. Variable description, descriptive statistics, and sources can be found in Appendix 1. 
Table 1.6. Contagion - Using Dummy Dependent Variables

\begin{tabular}{|c|c|c|c|c|}
\hline & \multicolumn{2}{|c|}{ Geography } & \multicolumn{2}{|c|}{ Trade } \\
\hline & \multicolumn{2}{|c|}{ Dependent Variable } & \multicolumn{2}{|c|}{ Dependent Variable } \\
\hline & $\begin{array}{l}\text { Currency } \\
\text { Crisis }\end{array}$ & $\begin{array}{c}\text { Currency } \\
\text { Stability }\end{array}$ & $\begin{array}{l}\text { Currency } \\
\text { Crisis }\end{array}$ & $\begin{array}{l}\text { Currency } \\
\text { Stability }\end{array}$ \\
\hline $\begin{array}{l}\text { Independent } \\
\text { Variable }\end{array}$ & SAR & SAR & $\begin{array}{l}\text { SAR- Exports and } \\
\text { bilateral trade weight }\end{array}$ & $\begin{array}{l}\text { SAR-Exports } \\
\text { and bilateral trade } \\
\text { weight }\end{array}$ \\
\hline Constant & $\begin{array}{l}0.159 * * \\
(2.051)\end{array}$ & $\begin{array}{l}0.711 * * * \\
(8.500)\end{array}$ & $\begin{array}{l}0.160 * * \\
(2.055)\end{array}$ & $\begin{array}{l}0.537 * * * \\
(5.167)\end{array}$ \\
\hline Lambda & $\ldots$ & $\ldots$ & $\ldots$ & $\ldots$ \\
\hline Rho & $\begin{array}{l}0.066^{* * * *} \\
(6.540)\end{array}$ & $\begin{array}{l}0.126 * * * \\
(3.852)\end{array}$ & $\begin{array}{l}0.053 * * * \\
(3.404)\end{array}$ & $\begin{array}{l}0.308 * * * \\
(4.107)\end{array}$ \\
\hline $\begin{array}{l}\text { LaggedCrises } \\
\text { Current Account } \\
\text { per GDP } \\
(\text { annual \%) }\end{array}$ & $\begin{array}{l}\cdots \\
0.003^{*} \\
(1.679)\end{array}$ & $\begin{array}{l}\cdots \\
0.003^{*} \\
(-1.556)\end{array}$ & $\begin{array}{l}\cdots \\
0.003 * \\
(1.722)\end{array}$ & $\begin{array}{l}\cdots \\
-0.004^{*} \\
(-1.879)\end{array}$ \\
\hline $\begin{array}{l}\text { Domestic Credit } \\
\text { per GDP growth } \\
\text { (annual \%) }\end{array}$ & $\begin{array}{c}0.00002 \\
(0.199)\end{array}$ & $\begin{array}{r}-0.00003 \\
(-0.199)\end{array}$ & $\begin{array}{l}0.00003 \\
(0.201)\end{array}$ & $\begin{array}{l}-0.00003 \\
(-0.176)\end{array}$ \\
\hline $\begin{array}{l}\mathrm{M} 2 \text { - money and } \\
\text { quasi money to } \\
\text { total reserve ratio }\end{array}$ & $\begin{array}{l}-0.00006 \\
(-0.229)\end{array}$ & $\begin{array}{l}0.0002 \\
(0.881)\end{array}$ & $\begin{array}{l}-0.00006 \\
(-0.233)\end{array}$ & $\begin{array}{r}0.0002 \\
(0.728)\end{array}$ \\
\hline CPI (annual \%) & $\begin{array}{l}-0.00002 \\
(-0.844)\end{array}$ & $\begin{array}{l}0.00003 \\
(1.271)\end{array}$ & $\begin{array}{l}-0.00002 \\
(-0.867)\end{array}$ & $\begin{array}{l}0.00003 \\
(1.315)\end{array}$ \\
\hline $\begin{array}{l}\text { GDP growth } \\
\text { (annual \%) }\end{array}$ & $\begin{array}{l}-0.008 * * * \\
(-4.304)\end{array}$ & $\begin{array}{l}0.012 * * * \\
(6.169)\end{array}$ & $\begin{array}{l}-0.009 * * * \\
(-4.424)\end{array}$ & $\begin{array}{l}0.012 * * * \\
(6.420)\end{array}$ \\
\hline $\begin{array}{l}\text { Unemployment } \\
\text { (annual \%) }\end{array}$ & $\begin{array}{l}-0.010 * * * \\
(-4.225)\end{array}$ & $\begin{array}{l}0.011 * * * \\
(4.615)\end{array}$ & $\begin{array}{l}-0.010 * * * \\
(-4.275)\end{array}$ & $\begin{array}{l}0.011 * * * \\
(4.615)\end{array}$ \\
\hline $\begin{array}{l}\text { Regional } \\
\text { Dummies }\end{array}$ & Yes & Yes & Yes & Yes \\
\hline Island & $\begin{array}{l}-0.017 \\
(-0.402)\end{array}$ & $\begin{array}{l}0.133 * * * \\
(2.761)\end{array}$ & $\begin{array}{l}-0.026 \\
(-0.601)\end{array}$ & $\begin{array}{l}0.049 \\
(1.153)\end{array}$ \\
\hline Observations & 119 & 119 & 119 & 119 \\
\hline R-squared & 0.090 & 0.126 & 0.089 & 0.131 \\
\hline Log-likelihood & -0.45343073 & 6.4585471 & -1.643789 & 7.4175162 \\
\hline
\end{tabular}

Notes: t-statistics in parentheses; asterisks indicate significance as follows: $* * *=1 \%, * *=5 \%, *=10 \%$. Variable description, descriptive statistics, and sources can be found in Appendix 1. 


\section{Chapter 3}

\section{The Spread of Financial Development}

\subsection{Introduction}

The increased focus on financial development (a measure of the credit advanced to the private sector in a country) in both the development and finance literature comes mainly from its believed role in promoting economic growth during the recent trend towards globalization. For example, high risks of expropriation and thus insecure property rights limit financial development and the ability of a country to take advantage of financial globalization. Moreover, financial development is one of the prerequisites for a country to realize the full growth potential of FDI. Domestic banking development is one of the important requirements in exploiting growth opportunities. (Stulz, 2005; Hermes and Lensink, 1999; Bekaert, Harvey, Lundblad and Siegel, 2007).

There is a positive relationship between private sector enforcement, financial development and investment and growth. It is also documented that the effect of liberalization on economic growth is greater if a country starts from above average level of financial development. Researchers have empirically shown evidence supporting the Schumpeterian theory of convergence that countries with a certain critical level of financial development have a likelihood of converging to the world-technology frontier and that other countries have far lower long-run growth. (Johnson, McMillan and Woodruff, 2002; Bekaert, Harvey, and Lundblad, 2005; Aghion, Howitt, and Mayer-Fulkes, 2003).

The foregoing literature has many implications, including but not limited to the following: as countries make every possible effort to converge to the world's technological frontier, for the convergence theory to hold, countries need to attain a certain threshold of 
financial development; governments of countries may need to booster domestic investment by encouraging both actual and potential entrepreneurs to secure the necessary funds needed for such ventures; globalization can lead to competition between domestic and foreign lenders for customers (potential and actual entrepreneurs and investors). The first two points listed above begs the question how do countries attain the necessary level of financial development? While a few papers such as Koubi (2008) have addressed issues like the determinants of financial development, no paper has examined whether financial development is contagious.

This chapter tests whether the amount of private credit being advanced to the private sector in one country depends on what is prevailing in the private credit markets of other countries. Second, it attempts to find out what the transmission mechanisms are and what the magnitude of the contagion is in each case. This chapter therefore examines how countries attain the necessary level of financial development needed for growth convergence. It identifies three channels of contagion in financial development namely financial linkages, trade and geography.

My results suggest that each of these is a significant channel through which financial development can spread from one country to the other. Specifically, it finds which channel is more effective and more responsible for the spread and growth of financial development in countries. Whiles no single channel seem to be the sole means of transmission, my results show that Financial linkages are a more effective means followed closely by trade and geography. In section 2, I shortly explain each of these channels; section 3 expatiates on the methodology and data followed by presentation of my results and conclusion in sections 4 and 5 respectively 


\subsection{Transmission Mechanisms of Financial Development}

\subsubsection{Geography as a channel of Financial Development}

The geographic spread of financial development is fostered by economic unions and the activities of a common lender to a regional block.

One way financial development can spread by geography is through economic unions. Through economic unions like NAFTA or the EU, financial development can spread to member countries which join such unions. Cvetanovic (2006) shows how the EU can, for example, contribute to the financial development of the eight former-Socialist European accession (EU-8) countries that joined it. The paper argues that through the activities of institutional investors (domestic and foreign) such as insurance companies, mutual funds and private pension funds there will be liquidity boost in terms of share of turnover in the market and a reduction in the cost of capital, which would make it easier for liquidity-constrained firms in the union to obtain fresh capital infusion.

Finally, a regional block having a common lender can experience similar financial development, especially changes of financial development in their geographical location. Kaminsky and Reinhart (2000) explain that when a common creditor country has nonperforming loans in one of its customer countries in a regional block it may chose to reduce or withdraw its credit advances to the country involved as well as customer countries in the entire block. This was what happened during the Asian crisis when Japan happened to be a common lender to most of the Asian countries. 


\subsubsection{Trade as a channel of Financial Development}

Trade is another major way financial development can spread. Rajan and Zingales (2003a, 2003b) show that financial development is associated with trade liberalization. They document that "periods when and countries where borders were open to foreign trade and capital coincided with periods of intense financial development. This is true even controlling for endogeneity of the decision to open up borders". According to their findings, even though special interest groups could have strong motives to hinder the development of a good financial sector, openness to international trade and capital flows could mitigate these incentives.

Second, trade openness leads to increased competition from foreigners. To be able to compete with foreign countries, especially more developed countries, poorer countries need to attain a certain critical level of financial development and would enforce financial development. Firms and entrepreneurs would put pressure on their governments to make legislations that would make financial development thrive to enable them compete in the global marketplace.

\subsubsection{Financial linkages as a channel of Financial Development}

Financial linkages between countries can also have spillover effects on countries' level of financial development. In other words, a country that has financial linkages with other countries with different levels of financial development will have its financial sector affected differently by each of those countries.

For example, the spillover effects of FDI have been explored by many researchers. Lipsey (2000) shows that there has been an increased capital formation in Canada as a result of FDI inflows. Also, Dutta and Roy (forthcoming) find that FDI has positive spillover effects on 
a country's institutional framework. They document that not only will FDI bring technology spillovers into a country but that it also ensures better corporate governance, efficient laws, better legal environments and financial comfort ( $\mathrm{FDI}^{1}$ is thus used to weigh financial linkages in this study). Financial development, being also a formal institution, is therefore liable to receiving this positive spillover either directly or indirectly.

Financial linkages can either be direct or indirect. Directly, financial linkages can be in the form of private credit unions or financial institutions established by foreign firms (primarily for their employees), which can eventually help in establishing financial development in the domestic countries. Indirectly, it could also go beyond this point to have a ripple effect through competition, learning, and motivation. First, domestic private lenders would compete with foreign credit unions or financial institutions that have better credit risk and monitoring expertise. In order not to lose customers (borrowers) to these firms they would seek a better system that will enable them to efficiently advance credit.

Second, domestic lenders also have the opportunity to learn the expertise (such as the ability to distinguish good credit risks from bad credit risks) from these foreign lenders and hence be in a better position to advance more credit to the private sector.

\subsection{Data and Methodology}

\subsubsection{Dependent Variables}

For the purpose of this chapter, I consider three measures of financial development namely domestic credit to the private sector as a percentage of GDP, private credit by the banking sector as a percentage of GDP, and stock market total value traded as a percentage of GDP.

\footnotetext{
${ }^{1}$ While there apparently are causality issues between FDI and financial development especially at low levels of financial development (Rioja and Valev 2004), this paper just uses FDI to construct a weight matrix to proxy for financial linkages and does not use FDI itself as an explanatory variable.
} 
The first two measure domestic banking development and banking development respectively. Domestic credit to the private sector includes credit from all domestic sources (private and public) to the private sector. Private credit banking sector includes credit from all commercial banks from home and abroad. The last one relates to stock market liquidity and measures stock market development. Domestic credit to the private sector as a percentage of GDP is used for the main analysis while the rest two measure domestic banking development and banking development respectively while the last one relates to stock market liquidity and measures stock market development. Domestic credit to the private sector as a percentage of GDP is used for the main analysis while the rest are for robustness checks.

In addition to a specification estimating the level of financial development level, I will also consider a specification using change of financial development. This change specification examines whether credit freezes or other shocks are also contagious. Data is from 1985-2000. The data for financial development comes from World Development Indicator (WDI). Data descriptions and statistics are found in appendix 3.

\subsubsection{Independent Variables}

The independent variables used in this study include initial GDP per-capita, the lagged level of financial development, spatial weight matrixes and regional or continent dummies. Lagged levels of countries' financial development are included to examine if there is any evidence of institutional dependence; that is if previous levels of financial development affect the present. Data for these variables is also taken from the World Development Indicator Series Data (WDI).

Other variables are the indexes of bureaucratic quality, the risk of expropriation of private investment, the risk of repudiation of contracts by governments and legal environment, which is 
the summation of the last two indicators. Higher values of the bureaucratic quality index indicate that bureaucratic delays are low or the bureaucratic structure of the country is high. High values of the risk of expropriation index, the risk of repudiation of contracts and hence the legal environment means that it is safer to transact business in such a country. In other words, governments are not likely to confiscate private investment or inadvertently alter contracts or arbitrarily change business agreements with foreign investors. Data for these measures are taken from the ICRG dataset.

For the measures of geography I collect data on nearest neighbors from the World Fact Book. The trade data is taken from the IFS Direction of Trade databases. FDI data comes from the OECD data base on the bilateral FDI inflows from countries. The FDI data comprises of only data on the OECD countries due to unavailability of data; only the OECD countries provide data on FDI inflows from other countries and hence the weight matrix can only be constructed for these countries. The full sample however comprises of a panel of 98 countries for the geography regression and the trade regression and a panel of 30 countries for the FDI regression. Five years averages are computed and used for panel regressions.

\subsubsection{Methodology}

This study uses spatial econometric methods to examine the spread of financial development. I will use both a spatial autoregressive model (SAR) and spatial error model (SEM). SAR specifies a country's financial development as a function of the weighted value of the financial development of its geographic neighbors, trade partners, and FDI partner. SEM models the error term of a country's financial development as a function of the weighted value of its geographic 
neighbors' errors, trade partners' errors, and FDI partner's errors. The regression uses five year averages for a panel regression.

These models are specified below:

These models are specified below:

SAR:

$$
Y_{t}=\alpha+\rho W Y_{t}+\beta X_{t}+v_{t}
$$

SEM :

$$
Y_{t}=\alpha+\beta X_{t}+\varepsilon_{t} ; \quad \varepsilon_{t}=\lambda W \varepsilon_{t}+\eta_{t}
$$

where $W$ is an NXN weight matrix with respect trade or geography; $X_{t}$ is a vector of controls variables, $Y_{t}$ is an NX1 vector of measures of the dependent variables; $\rho$ and $\lambda$ are the spatial autoregressive and spatial error coefficients respectively (which represent the percentage of a country's dependent variable accounted for by the dependent variable of its trade linkages or geographic neighbors), and $v_{t}$ and $\varepsilon_{t}$ are NX1 matrixes of iid random errors.

To use this approach, I will first test for the presence of spatial dependence using the Lagrangian Multiplier (LM) test which shows whether OLS estimates would be biased and also helps chose the best spatial model (the one with the largest LM t-statistic). I use both models in my analysis; based on my test, SEM is the best model for the analysis. While I ran both regressions only the SEM results are reported.

\subsubsection{Weight Matrixes}

I construct a spatial weight matrix for geographic neighbors, FDI and trade partners as in Leeson and Sobel (2006). For financial linkages the weight country A assigns to each country is calculated as the ratio of each country's FDI partner's inflows to the country's total FDI inflows. 
The same applies to the trade weight matrix, where the weight is calculated as a percentage of the imports of partner countries to country A's total imports. In matrix notation this is represented below:

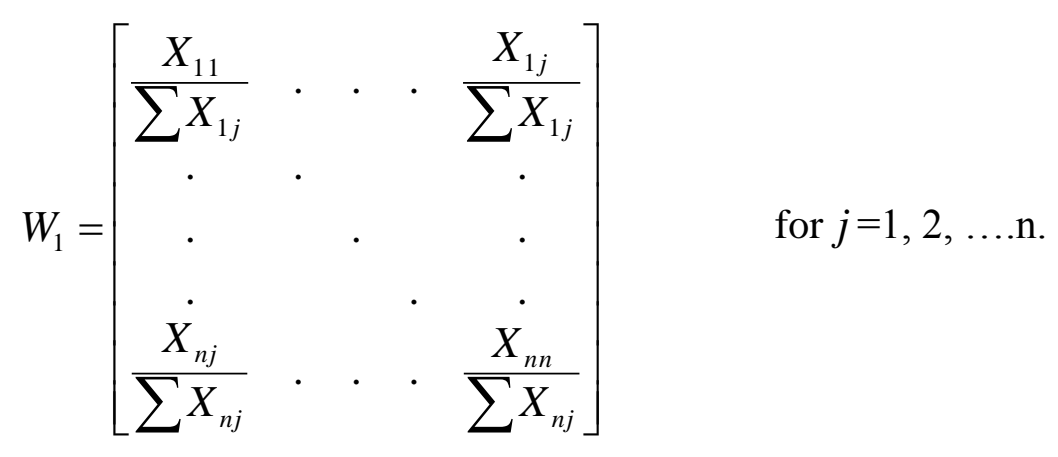

where $X_{i, j}$ represents imports or FDI inflows from country $j$ to country $i$.

For the geography weight matrix, I use the "queen" case of first order contiguity. Thus a country gives a weight of one to every country it shares a border with (whether vertically, horizontally or at vertex contacts) and zero otherwise. As with the other weight matrices above, the geography weight matrix is row standardized. In other words the weight given by each country to geographic neighbors is calculated as a ratio of 1 to the total number of the countries that each country shares neighbors with. For example, if country A has 4 neighbors, then each of these countries is assigned a weight of $1 / 4$ by country A.

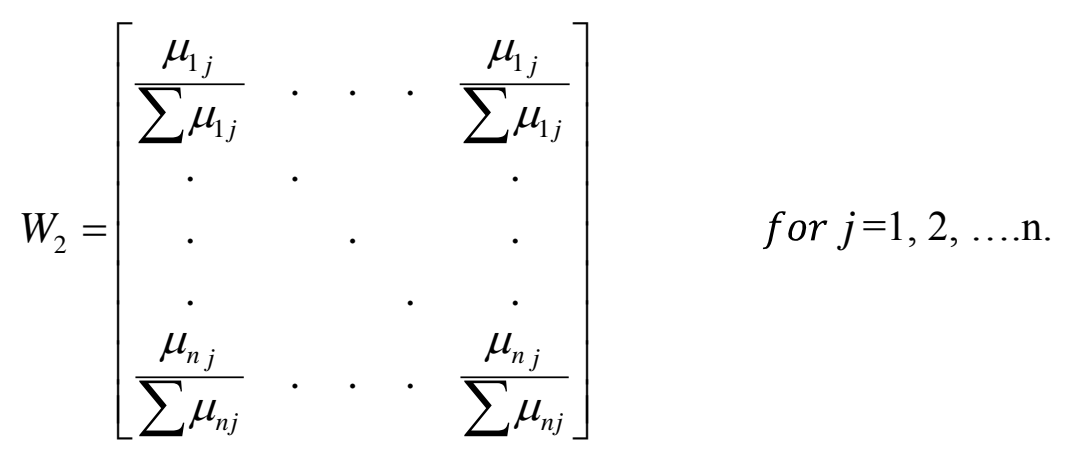


where $\mu_{i j}=\left\{\begin{array}{cc}1 & \text { if country iand jareneighbors } \\ 0 & \text { otherwise }\end{array}\right.$

This makes the weights given by each country to all others sum up to 1 . This is represented in matrix notations above.

The problem with geography though is that countries which are islands may not be assigned any weights. To deal with this problem, I assigned a dummy which takes a value one if a country is an island and zero otherwise. If the island dummy is insignificant it will be dropped, otherwise this will necessitate running the regression without islands.

In the following sections, I will present my results, analyze it, recommend policies and conclude.

\subsection{Results}

Table 2.1 shows the result for geography while Table 2.2 and Table 2.3 show results for trade and Financial linkages respectively. Column 4 of all tables show the results for financial development (measured as domestic credit to the private sector as a percentage of GDP) when all control variables are used, including the lagged level of financial development. The Financial linkgages results do not include lagged levels due to insufficient data. Column 8 of Table 2.1 and Table 2.2 and column 3 of Table 2.3 show the results for change of financial development.

The result shows that there is contagion both in levels and first differences in financial development. That is, countries linked to others (by geography, trade or financial linkages) with high levels of financial development tend to "catch" high levels of financial development. This is also true when countries are linked to others experiencing changes of financial development (such as credit freezes or other shocks). Also, this study finds that financial linkages are the 
dominant channel of contagion followed by trade and geography. The SEM regression results are the ones reported for analysis based on the LM tests.

The value of lambda shows contagion in financial development. At levels this is 0.184 , 0.19 and 0.272 for geography, trade and financial linkages respectively. In other words, countries catch $0.184,0.19$ and 0.272 of their neighbors' levels of financial development, their trade partners' levels of financial development and their financial linkage countries' levels of financial development respectively. Since the Financial linkages regression does not have a lagged term as the other regressions, for robustness checks, I run the regression using other dependent variables. Column 2 of Table 2.3 shows that the contagion at levels of financial development (measured as stock market total value traded as a percentage of GDP) is 0.44 . All results are significant at the 1 percent level.

Contagion in changes of financial development is 0.185 , and 0.187 for geography and trade respectively. Since the financial linkages regression does not have a lagged term as the other regressions, I have no results for the contagion in the changes of financial development measured as domestic credit to the private sector through financial linkages. However, Table 2.3 shows that contagion through financial linkages, using change of private credit by the banking sector (banking development) as the dependent variable, is 0.289 . These results are significant at the 5 percent, 5 percent and 10 percent levels for geography, trade and financial linkages respectively.

The chapter also finds lagged levels of financial development to account significantly and positively for the level of financial development, but negatively for the changes of financial development. The coefficient on lagged FD shows that lagged levels of financial development accounts for 89 percent of the level of financial development in a country. 
The results are all significant at 1 percent level. This means that there is evidence of institutional dependence at levels of financial development. Thus countries with previous high levels of financial development would tend to have higher levels of financial development than countries with lower levels of financial development.

However, changes in financial development tend to inversely correlate with lagged levels of financial development, implying convergence. The results show that lagged levels of financial development inversely accounts for 11 percent of the change of financial development in a country. These are all significant at the 1 percent levels.

The chapter also finds bureaucratic quality important for financial development. This is especially true in the trade and geography regressions where bureaucratic quality accounts for about 3.6 percent and 2.7 percent respectively. These can be found in Table 2.1 and Table 2.2. Legal environment is found to matter only for change of financial development, measured as domestic banking development. This is found Table 3 in the financial linkages regression. The results indicate that legal environment is negatively related to changes of private credit by the banking sector and this accounts for about 10.5 percent. In other words the lower the level of legal uncertainty in a country, the higher the change of financial development. This finding supports Koubi (2008). Separately, the risk of expropriation and the risk of repudiation of contracts do not seem to matter in all regressions.

Finally, in all regressions, the chapter finds per capita GDP as only statistically significant but not economically significant for financial development. The coefficient on per capita GDP in all tables indicates that per capita GDP is only statistically significant at 1 per 


\subsection{Conclusion}

This chapter examines whether financial development is contagious and finds evidence of contagion through geography, trade and financial linkages. While none of these channels seem to be solely responsible for the spread of financial development, the chapter finds financial linkages as the dominant channel both at levels and at first difference followed by trade and geography, which seem to have similar magnitudes of contagion. The result for contagion for change of financial development and levels of financial development are very close, suggesting that changes of financial development, such as credit freezes, are almost as contagious as levels of financial development.

The chapter also finds evidence of institutional dependence at levels of financial development. This implies that countries with high previous levels of financial development tend to have higher levels of financial development than countries with lower previous levels of financial development. The findings of this chapter also suggest a positive relationship between financial development and bureaucratic quality and a negative relationship between financial development and the legal environment.

Based on the findings of this chapter, a suggestion to developing countries as well as multilateral corporations would be to establish more financial linkages and trade links between developing countries and the developed world especially in the area of stock market development. This would be more effective in an environment of bureaucratic efficiency and low legal uncertainty. 
Table 2.1: Geographic Contagion

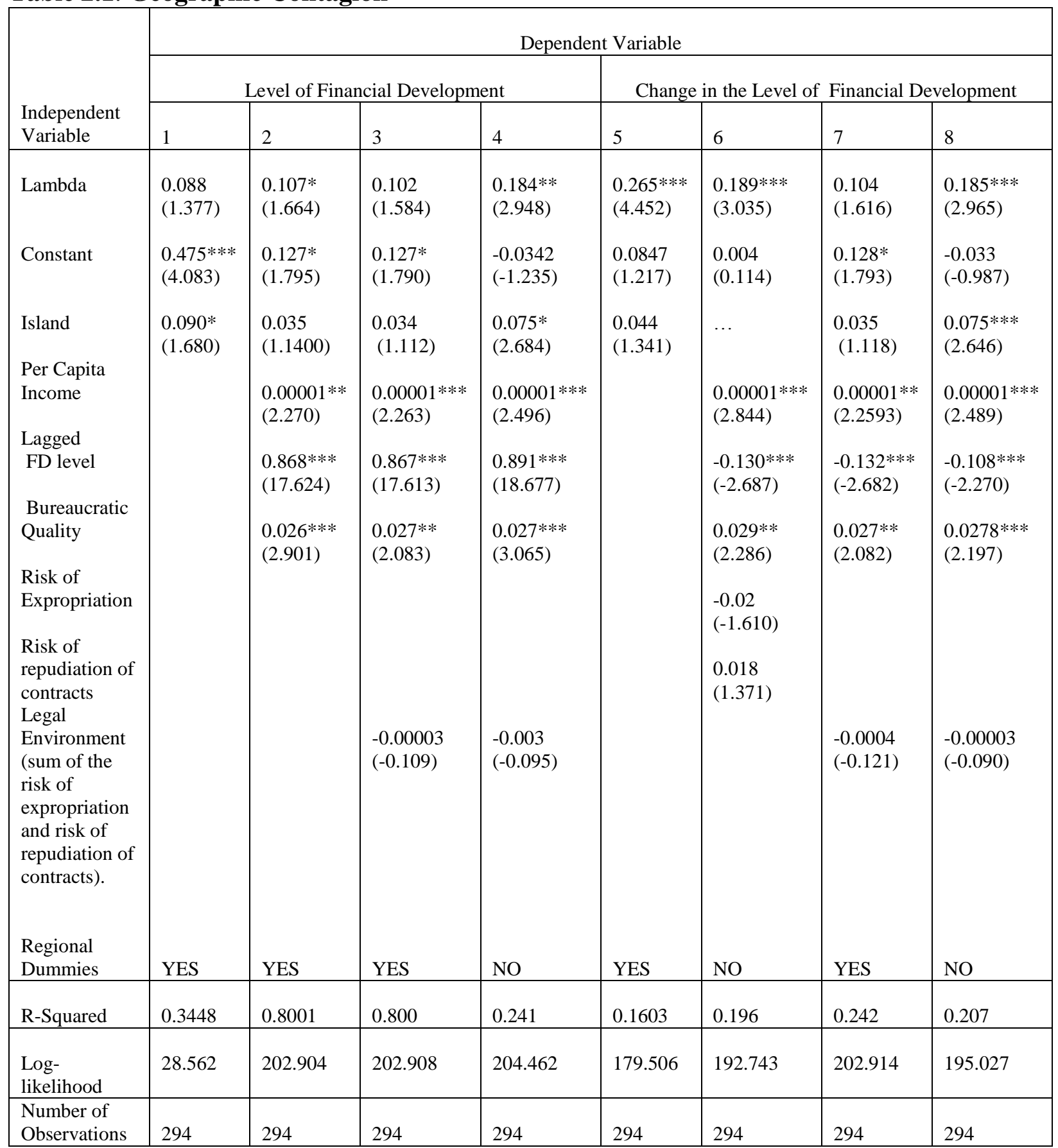

Notes: t-statistics in parentheses; asterisks indicate significance as follows: $* * *=1 \%, * *=5 \%, *=10 \%$. Variable description, descriptive statistics, and sources can be found in Appendix 3. 
Table 2.2: Trade Contagion

\begin{tabular}{|c|c|c|c|c|c|c|c|c|}
\hline \multirow{3}{*}{$\begin{array}{l}\text { Independent } \\
\text { Variable }\end{array}$} & \multicolumn{8}{|c|}{ Dependent Variable } \\
\hline & \multicolumn{4}{|c|}{ Level of Financial Development } & \multicolumn{4}{|c|}{ Change in the Level of Financial Development } \\
\hline & 1 & 2 & 3 & 4 & 5 & 6 & 7 & 8 \\
\hline Lambda & $\begin{array}{l}0.163^{*} \\
(1.660)\end{array}$ & $\begin{array}{l}0.202 * * \\
(2.104)\end{array}$ & $\begin{array}{l}0.171^{*} \\
(1.750)\end{array}$ & $\begin{array}{l}0.190 * * \\
(1.965)\end{array}$ & $\begin{array}{l}0.426 * * * \\
(5.303)\end{array}$ & $\begin{array}{l}0.201 * * \\
(5.231)\end{array}$ & $\begin{array}{l}0.174 * \\
(1.795)\end{array}$ & $\begin{array}{l}0.187 * * \\
(1.961)\end{array}$ \\
\hline Constant & $\begin{array}{l}0.434 * * \\
*(3.719)\end{array}$ & $\begin{array}{l}0.135^{*} \\
(1.889)\end{array}$ & $\begin{array}{l}0.129 * \\
(1.798)\end{array}$ & $\begin{array}{l}-0.027 \\
(-0.848)\end{array}$ & $\begin{array}{l}0.066 \\
(0.925)\end{array}$ & $\begin{array}{l}0.135^{*} \\
(1.889)\end{array}$ & $\begin{array}{l}0.127 * \\
(1.798)\end{array}$ & $\begin{array}{l}0.027 \\
(-0.847)\end{array}$ \\
\hline Island & $\begin{array}{l}0.087^{*} \\
(1.667)\end{array}$ & $\begin{array}{l}0.023 \\
(0.781)\end{array}$ & $\begin{array}{l}0.029 \\
(0.925)\end{array}$ & & $\begin{array}{l}0.036 \\
(1.162)\end{array}$ & $\begin{array}{l}0.024 \\
(0.781)\end{array}$ & $\begin{array}{l}0.028 \\
(0.920)\end{array}$ & \\
\hline $\begin{array}{l}\text { Per Capita } \\
\text { Income }\end{array}$ & & $\begin{array}{l}0.0000004 \\
(1.619)\end{array}$ & $\begin{array}{l}0.000004 * \\
(1.820)\end{array}$ & $\begin{array}{l}0.00001 * * * \\
(2.713)\end{array}$ & & $\begin{array}{l}0.000004 \\
(1.622)\end{array}$ & $\begin{array}{l}0.000004 * \\
(1.807)\end{array}$ & $\begin{array}{l}0.00001 * * * \\
(2.715)\end{array}$ \\
\hline $\begin{array}{l}\text { Lagged } \\
\text { FD level }\end{array}$ & & $\begin{array}{l}0.852 * * * \\
(17.270)\end{array}$ & $\begin{array}{l}0.866^{* * * *} \\
(17.681)\end{array}$ & $\begin{array}{l}0.888^{* * * *} \\
(18.388)\end{array}$ & & $\begin{array}{l}-0.148 * * * \\
(-2.991)\end{array}$ & $\begin{array}{l}-0.133 * * * \\
(-2.719)\end{array}$ & $\begin{array}{l}-0.111 * * * \\
(-2.297)\end{array}$ \\
\hline $\begin{array}{l}\text { Bureaucratic } \\
\text { Quality }\end{array}$ & & $\begin{array}{l}0.033 * * * \\
(2.597)\end{array}$ & $\begin{array}{l}0.034 * * * \\
(2.597)\end{array}$ & $\begin{array}{l}0.036 * * * \\
(2.880)\end{array}$ & & $\begin{array}{l}0.033 * * * \\
(2.594)\end{array}$ & $\begin{array}{l}0.033 * * \\
(2.611)\end{array}$ & $\begin{array}{l}0.036 * * * \\
(2.876)\end{array}$ \\
\hline $\begin{array}{l}\text { Risk of } \\
\text { Expropriation } \\
\text { Risk of } \\
\text { repudiation of } \\
\text { contracts }\end{array}$ & & $\begin{array}{l}-0.024 * * \\
(-2.042) \\
0.021 \\
(1.639)\end{array}$ & & & & $\begin{array}{l}-0.024 * * \\
(-2.039) \\
0.021 \\
(1.638)\end{array}$ & & \\
\hline $\begin{array}{l}\text { Legal } \\
\text { Environment } \\
\text { (sum of the } \\
\text { risk of } \\
\text { expropriation } \\
\text { and risk of } \\
\text { repudiation } \\
\text { of contracts). }\end{array}$ & & & $\begin{array}{l}-0.002 \\
(-0.632)\end{array}$ & $\begin{array}{l}-0.0003 \\
(-0.777)\end{array}$ & & & $\begin{array}{l}-0.002 \\
(-0.652)\end{array}$ & $\begin{array}{l}-0.0003 \\
(-0.770)\end{array}$ \\
\hline $\begin{array}{l}\text { Regional } \\
\text { Dummies } \\
\end{array}$ & YES & YES & YES & NO & YES & YES & YES & NO \\
\hline R-Squared & 0.3515 & 0.804 & 0.8014 & 0.7817 & 0.1605 & 0.257 & 0.247 & 0.172 \\
\hline Log-likelihood & 29.924 & 205.604 & 203.857 & 189.761 & 179.5548 & 205.605 & 203.861 & 194.149 \\
\hline $\begin{array}{l}\text { Number of } \\
\text { Observations }\end{array}$ & 294 & 294 & 294 & 294 & 294 & 294 & 294 & 294 \\
\hline
\end{tabular}

Notes: t-statistics in parentheses; asterisks indicate significance as follows: $* * *=1 \%, * *=5 \%, *=10 \%$. Variable description, descriptive statistics, and sources can be found in Appendix 3. 
Table 2.3: Financial Linkages Contagion

\begin{tabular}{|c|c|c|c|c|}
\hline \multirow[b]{2}{*}{$\begin{array}{l}\text { Independent } \\
\text { Variable }\end{array}$} & \multicolumn{4}{|c|}{ Dependent Variables } \\
\hline & $\begin{array}{l}\text { Stock Market } \\
\text { Total Value } \\
\text { Traded } \\
(\% \text { GDP })\end{array}$ & $\begin{array}{l}\text { Stock Market Total } \\
\text { Value Traded } \\
(\% \text { GDP })\end{array}$ & $\begin{array}{l}\text { Change in the level } \\
\text { of Private Credit by } \\
\text { the Banking Sector } \\
\text { (\% GDP) }\end{array}$ & $\begin{array}{l}\text { Domestic Credit to the } \\
\text { Private Sector } \\
(\% \text { GDP) }\end{array}$ \\
\hline Lambda & $\begin{array}{l}0.458 * * * \\
(3.971)\end{array}$ & $\begin{array}{l}0.440 * * * \\
(3.734)\end{array}$ & $\begin{array}{l}0.289 * * \\
(2.122)\end{array}$ & $\begin{array}{l}0.272 * * \\
(1.980)\end{array}$ \\
\hline Constant & $\begin{array}{l}-0.064 \\
(-0.222)\end{array}$ & $\begin{array}{l}0.204 \\
(0.702)\end{array}$ & $\begin{array}{l}-1.952 * * * \\
(-3.308)\end{array}$ & $\begin{array}{l}0.099 \\
(0.289)\end{array}$ \\
\hline Island & $\begin{array}{l}0.395 * * * \\
(2.725)\end{array}$ & $\begin{array}{l}-0.012 \\
(-0.185)\end{array}$ & $\begin{array}{l}0.053 \\
(0.334)\end{array}$ & \\
\hline $\begin{array}{l}\text { Per Capita } \\
\text { Income }\end{array}$ & $\begin{array}{l}0.00001 * * * \\
(2.972)\end{array}$ & $\begin{array}{l}0.00001^{* * * *} \\
(2.643)\end{array}$ & $\begin{array}{l}0.00001 \\
(1.054)\end{array}$ & $\begin{array}{l}0.00002 * * * \\
(6.506)\end{array}$ \\
\hline Lagged FD level & & & & \\
\hline $\begin{array}{l}\text { Bureaucratic Quality } \\
\text { Risk of Expropriation }\end{array}$ & $\begin{array}{l}0.053 \\
(1.331)\end{array}$ & $\begin{array}{l}0.052 \\
(1.257)\end{array}$ & $\begin{array}{l}-0.022 \\
(-0.284)\end{array}$ & $\begin{array}{l}0.023 \\
(0.476)\end{array}$ \\
\hline $\begin{array}{l}\text { Risk of repudiation of } \\
\text { contracts }\end{array}$ & & & & \\
\hline $\begin{array}{l}\text { Legal Environment } \\
\text { (sum of the risk of } \\
\text { expropriation and risk } \\
\text { of repudiation of } \\
\text { contracts) }\end{array}$ & $\begin{array}{l}-0.033 \\
(-1.528)\end{array}$ & $\begin{array}{l}-0.025 \\
(-1.076)\end{array}$ & $\begin{array}{l}0.105 * * \\
(2.324)\end{array}$ & $\begin{array}{l}0.002 \\
(0.009)\end{array}$ \\
\hline Regional Dummies & YES & NO & YES & NO \\
\hline R-Squared & 0.193 & 0.316 & 0.193 & 0.374 \\
\hline Log-likelihood & -30.257 & -148.298 & -30.257 & 5.588 \\
\hline $\begin{array}{l}\text { Number of } \\
\text { Observations }\end{array}$ & 90 & 90 & 90 & 90 \\
\hline
\end{tabular}

Notes: t-statistics in parentheses; asterisks indicate significance as follows: $* * *=1 \%, * *=5 \%, *=10 \%$.

Variable description, descriptive statistics, and sources can be found in Appendix 3. 


\section{Chapter 4}

\section{Is Ethno-linguistic Fractionalization Perpetuated in Africa?}

\subsection{Introduction}

Though many factors have been found to account for the underdevelopment of African countries, ethno-linguistic fractionalization has been gaining increasing attention in the development literature. For example, the relationship between institutions, ethno-linguistic fractionalization and growth has been explored by many researchers. This includes the indirect effects of colonial institutions on the ability of Africans to trade peacefully. Colonial institutions in Africa are found to have exacerbated fractionalization, which led to the poor growth of African countries. Alternatively, good institutions mitigate fractionalization and this leads to economic growth. Some of other findings are that ethno-linguistic fractionalization negatively impacts economic growth and policies in Africa, and this is responsible for poor growth in Africa (Leeson, 2005; Easterly, 2001; Easterly and Levine , 1997).

The relationship between linguistic diversity, political stability and democracy has also been examined. Linguistic diversity has positive impact on political instability. It is also discovered that democracy eliminates the negative impact of ethno-linguistic fractionalization on growth. There is also a positive relationship between ethnic homogeneity and trust and this relationship reinforces the positive relationship between trust and economic growth (Collier, 1999; Mauro, 1995; Knack and Keefer, 1997). Cunning and Fay (1993) also explore the relationship between long-run growth and ethno-linguistic fractionalization.

The relationship between colonization and growth has also been explored by many researchers. European colonization, for example, has a negative impact on growth. Colonial heritage, measured as the identity of the Metropolitan ruler and the degree of Economic 
Penetration (GNP/GDP), is the reason for low average growth rate of GDP per capita and the observed heterogeneities in Africa. This explains differences in investment-output ratio, education attainment and the index of ethno-linguistic fractionalization. It has also been established that there is a negative relationship between the number of years of colonial rule and growth. Also, by exploring the effect of ethnic, linguistic and religious fractionalization on the quality of growth, other findings are that linguistic and ethnic (racial) fractionalization are strongly negatively related to growth, but religious fractionalization is not (Bertocchi and Canova, 2002; Grier, 1999; Alesina, Devleeschauwer, Kurlat, Easterly and Wacziarg, 2003).

Some other works in the area of economics of language include the explanation of the evolution of languages, the investigation of the economic and demographic determinants of destination language proficiency among immigrants and the connection of the connection between trade and languages. These researchers claim that trade requires language. (Rubinstein, 1998; Chiswick, 2008; Smith, 1776).

While the main focus of Leeson (2005), for example, is that regardless of heterogeneity individuals can realize gains from trade, this chapter asserts that trade can lead to linguistic homogeneity in a society. In other words, if and as diverse individuals trade, the walls of linguistic fractionalization will eventually be lowered to the barest minimal if not utterly destroyed as a result of their interaction. The chapter posits that unless incidents and events such as destructive colonial policies that can sever the interaction of diverse individuals occur, African countries would have experienced an increase in trade. This increased trade would then lead to linguistic homogeneity.

Though many papers have looked at ethno-linguistic fractionalization and its effects on growth and development, no paper has empirically examined the determinants of ethno-linguistic 
fractionalization. This chapter fills the gap by providing an empirical analysis of ethno-linguistic fractionalization using both OLS and Spatial Autoregressive model (SAR). The rest of this chapter is organized as follows. In the following section I examine the possibility of ethnolinguistic fractionalization decline in Africa, followed by what exactly transpired during colonial rule, methodology, results, possibility of ethno-linguistic homogeneity and conclusion in sections $2,3,4,5,6$ and 7 respectively.

\subsection{The Possibility of Ethno-linguistic Fractionalization Decline in Pre-colonial Africa}

\subsubsection{Pre-colonial Africa and the Decline of Ethno-linguistic Fractionalization}

African countries are among the world's most ethnically diverse countries. According to Easterly and Levine (2001), African countries are among fourteen of the world's fifteen most ethnically heterogeneous societies, with Uganda being the world's number one. However, before colonization, though fractionalized, Africa was one big society with no official significant differences. In order to commute from one area to the other, people did not need any documents or permission as long as they had the means of transportation and traveled through other settlements peacefully.

Though sometimes special gifts and offerings were given to the chiefs and fetish priests of other societies through which one travelled or undertook business transactions, society was more relaxed and movement as well as assimilation into other societies and cultures was very common. Leeson (2005) points out how outsiders wanting to join a particular community gave special gifts to the Earth's Priests and agreed to respect the community's rituals (as a signal of credibility) and were given the possibility of trading with the existing group members. He also documents that this offer of gifts was rarely mandatory. 
This is accentuated by the fact that some languages and cultures are common to a lot of ethnic groups across African countries today. For example, there are at least three tribes in Ghana who speak same language as other tribes in Togo, Benin, Nigeria and Cote D'Ivoire. In other words, this shows that interaction of different societies through trade (free trade) was highly possible even in the face of fractionalization.

Domestic, long distance and international trade developed in Africa with the resultant social interaction between different ethnic groups prior to European's arrival on the continent (Cohen, 1969: 6). There were also commercial interactions in pre-colonial Africa to the extent of creating homogeneity between different diverse people (Thornton, 1995: 194). Thus, without any interruption, there was the possibility that the walls of fractionalization might be lowered to their minimal levels if not utterly destroyed.

One way ethno-linguistic fractionalization could have declined in the absence of colonial rule is that, with time, some languages and cultures could become dominant over others in each society or a lingua franca could have evolved without colonial interruption. In every society, each group is identified with a certain kind of occupation. Typical examples are farmers, (including shepherds who travel widely in search of pasture), and traders. The latter are very influential as they move from one place to the other and must interact with the indigenous people in order to transact business with them. Consequently, they tend to spread their language and culture from place to place. Commercial interactions 'help explain the great cultural similarities between many different peoples south of the equatorial forest' (Vansina, 1968: 325).

In Ghana, for example, out of many languages and dialects there are four dominant ones. One of these, Akan, is widely spoken because the ethnic group that speaks it (the Ashantis) trade widely and also dominate the entertainment (or music) industry, and they use their music and 
trade to spread the use of the language in the whole country. There is hardly a Ghanaian who cannot speak or understand at least a word or a phrase in Akan. Many believe that Ghana will one day adopt Akan as the national language.

There is no denying the fact that most countries that have adopted one language today have gone through an evolution similar to the one depicted above. This process of evolution from ethno-linguistic fractionalization and others reported in some papers relating to different countries' experience could have taken place in Africa too, but this was interrupted or slowed down as a result of colonization.

\subsubsection{Cost and Benefits of Learning a New Language in Pre-colonial Africa}

Chiswick (2008) points out that language skill is human capital, since it satisfies the three requirements of a human capital namely productivity, costliness and embodiment in a person. The first two of these attributes imply that there is a benefit and cost associated with learning, adopting or developing a language that will serve the common good of a fractionalized society as Africa. If the cost is higher than the benefit, then the society or individuals who make up the society will stick to their different languages, instead. The opposite holds as well.

One of the costs of learning a dominant language or developing a common language in pre-colonial Africa is time; it takes time for one to learn a new language, especially so for the old because, the older a person is the longer and more difficult it becomes. It could also take time for parents and relatives to teach the young this new language, but in pre-colonial Africa where interaction among diverse individuals is free the process could be much more expedited than it was, if any, under colonial rule. Chiswick (2008) points out that exposure to the dominant 
language is a determinant of the cost of learning the language. Apparently, this exposure was much easier in the absence colonial barriers and colonial immigration restriction policies.

Another determinant of the cost of learning a new language, according to Chiswick (2008) is social distance. Social distance was much smaller in pre-colonial Africa. I can still relate pre-colonial Africa society to some societies in Africa today. In the Volta Region of Ghana (Ghana was divided into nine regions by colonial masters), the dominant language is Ewe. Besides this language, there are many other languages. You can travel five miles away from one society where Ewe is spoken to another society where a different language is spoken. But since this minor society can interact freely with the native Ewe speaking society, almost all of them are proficient in Ewe though not necessary literate (may not be able to read or write Ewe). So the absence of barriers and social distance in pre-colonial Africa reduced the cost of learning a dominant language.

Another factor that determines the cost of learning a new language, as pointed out by Chiswick (2008), is "distance" between one's mother language and the dominant language. Though Africa has many languages, one thing these languages mostly have in common is the syllabus. You can almost write every language using a certain set of alphabets. There are many languages which have certain words in common as well. This means that it will be easy for a speaker of one African language to learn to speak another or most African languages.

One of the benefits of learning language skills is productivity. Chiswick (2008) points out that, language skills are productive in consumption activities. This implies that it will enable people to find good quality goods and services at lower prices. Trading in Africa, including today's, requires one's ability to negotiate prices and the more proficient you are in a trade language the higher your chances of success. 
Not only would learning a dominant language in pre-colonial Africa enable people do well in the market, it will also make them find good jobs in the labor market. Chiswick (2008) documents that, this will enable agents to execute their jobs efficiently. He also points out that other social benefits include one's ability to network and make a wide range of friends outside one's linguistic enclave and the enhancement of civic involvement by gaining full political and economic rights of the dominant spoken language community.

In pre-colonial Africa, learning the larger society's language could be seen as a signal of credibility and could result in gaining access to full benefits of the larger society. For example, Leeson (2005) points out that pre-colonial agents used signals such as property usage, religious practices and the individual's relationship to authority to minimize the social distance between sender and receiver to send their credibility to outsiders they wanted to trade with.

\subsection{The Worsening of Ethno-linguist Fractionalization during Colonial Rule}

Colonial rule did a lot to stymie the decline of ethno-linguistic fractionalization in Africa. Leeson (2005) explored the indirect effects of colonial institutions on the ability of Africans to trade peacefully. He explained how artificial colonial institutions such as forced allegiance to an authority disabled the signal that individuals look to when evaluating the credibility of outsiders to trade, which resulted in the creation of smaller sub-groups among broader ones to eliminate the risk of interacting with those who are remotely unknown. Thus this colonial distortion of trade further reduced social and commercial interaction that would expose individuals to and cause them to learn a trade language.

Second, colonial rule inhibited free movement of individuals in Africa and this was no environment for culture or linguistic convergence. Leeson (2005) points out that as opposed to 
pre-colonial Africa where people could come and go as they pleased, so that it was possible for people to be members of multiple communities and hence exchange with a wide range of individuals, colonial land policy created noise in this signal used to convey credibility by legally requiring colonial agents to stay attached to their ruler-allocated areas of land. Such a colonial policy also restricted migration as was the case of Basutoland in 1903 when colonial law forbade the provision of land to non-Basotho people.

Limited mobility under colonial rule was therefore one of the factors that reduced the need to adopt or learn the most widely spoken language(s) as the cost of doing so became more than the benefit, if any.

Another way colonization exacerbated ethno-linguistic fractionalization in Africa is that colonial masters separated African countries into territories which may never be reconciled to each other, perhaps, forever. The separation has far reaching consequences of maintaining ethnolinguistic borders especially across countries. As mentioned above, different African countries societies with common languages and cultures have now been divided by walls of colonization. Societies, who once saw themselves as one, though far apart, because of language and culture, now see each other as aliens.

Though the walls of ethno-linguistic fractionalization may gradually break down in each colony (now country) it may never break down across countries. This is because these colonies are now trained to see one another as different entities. For example, the people from the Volta Region of Ghana speak the same language and have same culture as about half the population of Togo, but are considered strangers in Togo and treated as such. On the other hand, this Volta Region of Ghana speaks totally a different language and has somewhat different culture from 
some regions of Ghana. The same is true of Akan (the most widely spoken language in Ghana) speaking Ivorians.

Moreover, colonization led to the proliferation of different institutions in Africa that made it difficult to reduce fractionalization. Leeson (2005) points out that, colonial created institutions severed the communication mechanism between socially heterogeneous individuals in Africa by reducing the signals (pre-colonial institutions) that enabled communication and interaction as this increased the cost of commercial interaction. Legal systems of each colonial Master are different and this made it difficult for Africa to adopt an institutional framework that supported continent-wide development initiatives such as free trade areas. These legal frameworks that distorted the already established ones before them helped perpetuate ethno-linguistic fractionalization.

Colonial rulers made matters worse by again dividing their colonies into regions and districts which still persist today. This was an attempt to facilitate colonial rule but now permanently left these internal groups at conflict with each other over lands, resources and domains. Leeson (2005) documents that colonial policy led to a break-down of the ability of African people to interact freely and, instead, led to a sharp increase in property disputes among Africans under colonialism.

Finally, one would have thought that the introduction of the language of the colonist should mitigate linguistic fractionalization but what happened was the exact opposite. Unlike Latin America where Spanish was imposed by colonial masters and everyone was supposed to learn this language, the introduction of the language of the colonist was intended for only a few selected Africans, who helped in the facilitation of communication of the colonial masters with 
the Africans. Specifically, the introduction of these languages was just to serve the means of the colonial masters in extracting from the continent.

One way this could have turned out to help Africa was that when a larger population of each country gets to learn the colonial master's language, it could help to promote homogeneity. However, one could only learn this language (official language) through formal education, which is costly. Only the very rich could afford this formal education. Easterly and Levine (1997) document that more than 90 percent of the population in most African countries does not speak the official language at home. In other words, these official languages tend to add to linguistic diversity in Africa rather than help in creating homogeneity.

The whole of Africa was not colonized by colonial masters speaking the same language. This means that ranging from the British to the Portuguese; four or more languages were added to the several languages spoken in Africa rather than replace them (a situation that would have helped linguistic fractionalization in Africa). If a greater proportion, if not all, of the population of Africa countries were able to speak its colonial master's language the outcome would have been close to desirable.

Post-colonial attempts to use the colonial master's language to reduce linguistic fractionalization in Africa did not result in anything different from failure. Most African countries made it mandatory for every school going person to learn the official language (colonial master's language) of another African country. An example is Ghana, which has all its neighbors colonized by France and hence speak French. Hence, every Ghanaian in high school was made to learn French after the mid 80's.

This project, however, did not seem to achieve the intended goal - to enable the average educated Ghanaian to communicate with citizens of neighboring countries who happen to speak 
French. The main reason for this failure is again attributable to the scars of colonization colonial barriers. Bertocchi and Canova (2002) document that the impact of colonization may survive past political independence and those colonies kept paying the consequences of their history even after independence was achieved.

Due to these colonial barriers, which has now become official barriers, even if one learns the neighbors' language he could do little with it (because hardly does anyone speak that language in Ghana) and hence tend to forget it a few years after leaving school. If there were no official barriers and people could travel freely to neighboring countries, say, to trade continuous use of the neighbors language could cause them to be proficient not only in their own official language, but also in the language of their neighboring countries.

Cameroon is an example of the possibility of speaking a second official language in the absence of colonial barriers. One part of Cameroon was colonized by the French and the other by the British. However, since these two regions do not have any official barriers, most Cameroonians who speak French also speak English and vice versa, though they may not be

equally proficient in both. This is because there is a free interaction between these two parts of Cameroon and as they trade or conduct any commercial activities they put into use the official languages they learnt at school thereby becoming more proficient in both. This same example may be true in the case of Canada.

\subsection{Methodology}

\subsubsection{Data}

This study estimates the impact of colonial rule (number of years of colonial rule) on ethnolinguistic fractionalization. The data comprises a cross-section of 46 African countries from 
1980-2000. Data on ethno-linguistic fractionalization is taken from two sources. The first one is the measure of linguistic fractionalization computed by Alesina, Devleeschauwer, Kurlat, Easterly and Wacziarg (2003). This variable is based on the shares of languages spoken as mother tongues. The reason for the choice of this variable is that it is entirely based on language and hence different from the effect of any racial or ethnic features.

Even though the reason for the separation of this variable by Alesina, Devleeschauwer, Kurlat, Easterly and Wacziarg (2003) was to show that in some cases ethnic fractionalization matters more for growth than just language diversity, in most of their main regression linguistic fractionalization does have a bigger effect (and higher level of significance) on growth than ethnic fractionalization. I thus employ both this variable and ethno-linguistic fractionalization in my regressions.

The ethno-linguistic measure is taken from ELF Dataset, which is compiled by researchers at the Miklukho-Maklai Ethnological Institute in the Soviet Union based on the probability that two randomly selected individuals in a country will belong to different ethno-linguistic groups. This data is available for 1961. Easterly and Levine (2001) document that many researchers including geolinguistics use this dataset.

The population, GNP and GDP data are taken from the World Bank's databases. One of the measures of colonial rule, colonial penetration (also referred to as "drain") is the ratio of a country's GNP to GDP in 1960 as in Bertocchi and Canova (2002). The lower the value of GNP the higher the level of colonial penetration and the lower the ratio. They use this as a measure of colonial drain following the drain of wealth thesis. According to them this measure captures how colonial surplus was further extracted by Metropolitan countries by reducing indigenous capital accumulation through repatriation of profits, pensions, interest on loans and salaries. 
Institutional measures are taken from the International Country Risk Guide (ICRG). Data on colonial rule is taken from the World Fact Book. The length of colonization was compiled based on Barro (1991) which provides data including dates of independence. A detailed description of the data, together with summary measures is given in Appendix 5.

\subsubsection{Model}

Both OLS and a spatial econometric model, SAR (Spatial Autoregressive Model) are employed. SAR specifies a country's ethno-linguistic fractionalization as a function of the weighted value of the ethno-linguistic fractionalization of its geographic neighbors. The models are specified below:

\section{OLS:}

$$
\begin{aligned}
\text { Elf }=\propto_{0}+\propto_{1} \text { Colrule }+\propto_{2} \text { Institution }+\propto_{3} \text { Colpen }+\propto_{4} \text { Britishdummy } \\
\\
+\propto_{5} \text { Frenchdummy }+\propto_{6} \text { Belgiumdummy }+\propto_{7} \text { Borderdummy ... }
\end{aligned}
$$

where, Colrule is the number of years a country has been colonized, Trade is the volume of bilateral trade between an African country and all other African countries, Polstability is the index of political stability in a country and Dummy equals 1 if a country's post colonial borders existed before colonial rule and zero otherwise. Colonial rule is expected to have positive impact on ethno-linguistic fractionalization.

SAR:

$$
Y_{t}=\alpha+\rho W Y_{t}+\beta X_{t}+v_{t}
$$


where $X_{t}$ is a vector of controls variables specified above, $Y_{t}$ is an NX1 vector of measures of the dependent variables; $\rho$ is the spatial autoregressive and spatial error coefficients (which represents geographic contagion in the dependent variable), and $v_{t}$ and $\varepsilon_{t}$ are NX1 matrixes of iid random errors. $W$ is an NXN weight matrix for geographic neighbors.

For the geographic weight matrix, I use the "queen" case of first order contiguity. Thus a country gives a weight of one to every country it shares a border with (whether vertically, horizontally or at vertex contacts) and zero otherwise. The geographic weight matrix is row standardized. In other words the weight given by each country to geographic neighbors is calculated as a ratio of 1 to the total number of countries that each country shares neighbors with. For example, if country A has 4 neighbors, then each of these countries is assigned a weight of $1 / 4$ by country A.

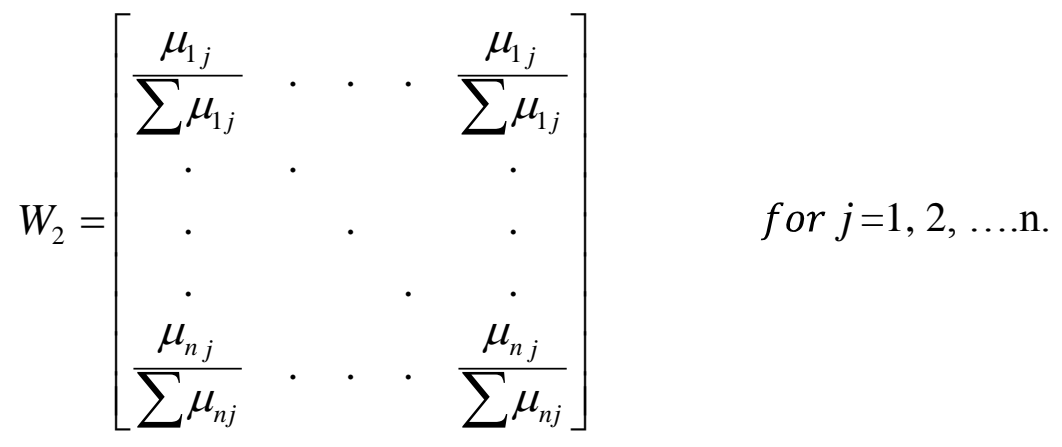

where $\mu_{i j}=\left\{\begin{array}{cc}1 & \text { if country i and jareneighbors } \\ 0 & \text { otherwise }\end{array}\right.$

This makes the weights given by each country to all others sum up to 1 . This is represented in matrix notations above. 
To use the SAR approach, I will first test for the presence of spatial dependence using the Lagrangian Multiplier (LM) test which shows whether OLS estimates would be biased and also helps to chose the best spatial model (the one with the largest LM t-statistic).

\subsection{Results}

\subsubsection{Main Findings}

The results suggest that the number of years of colonial rule in an African country affects both the country's volume level of linguistic fractionalization and ethno-linguistic fractionalization.

Table 3.1 shows that the impact of colonial rule on ethno-linguistic fractionalization and linguistic fractionalization is positive. The OLS regression results show that they are significant at $5 \%$ and $10 \%$ respectively. The significance of these results however depends on whether we control for institutions or not. For linguistic fractionalization, without controlling for institutions the number of years of colonial rule is insignificant. However, once I control for institutions both the number of years of colonial rule and institutions become significant. For ethno-linguistic fractionalization, the result flips; the number of years of colonial rule becomes insignificant when I control for institutions.

This could mean that while the number years of colonial rule matters for linguistic fractionalization and ethno-linguistic fractionalization, the effect of the number of years of colonial rule on linguistic fractionalization is exacerbated in face in the presence of weak institutions.

Similarly the colonial history dummies are significant in the linguistic fractionalization regressions only after controlling for institutions. The results (in both Table 3.1 and Table 3.2) suggest that British and French colonization worsened linguistic fractionalization in Africa. 
British colonization however, appears to reduce ethno-linguistic fractionalization when we do not control for institutions. This is shown in Table 3.1. Thus while British colonization seem to exacerbate linguistic fractionalization, it reduces ethno-linguistic fractionalization. A possible explanation for this could be that since the British practice a divide and rule system, it was able to merge different ethnic groups into one society creating an artificial ethnic group of many ethnic groups thereby replacing many natural ethnic groups by few artificial ones. However, people were not forced to abandon their native languages the way they were forced to be separated from their societies. Placing different ethnicities into one society (or now country) then increased the linguistic fractionalization in those societies as explained earlier.

Tangential to the above, colonial penetration is significant in all regression in Table 3.1 and Table 3.2. The results show that countries which have high level of "drain" (low colonial penetration ratio) are more fractionalized that countries which have low levels of "drain".

In Table 3.2, I report the results for the SAR model. The main aim of this regression is to find out if there is a spatial dependence in the dependent variables; that is if countries which have high levels of linguistic fractionalization or ethno-linguistic fractionalization tend to be neighbors. The result shows that linguistic fractionalization is contagious while ethno-linguistic fractionalization is not. This is evident in the coefficient of rho being significant in the SAR regression for linguistic fractionalization as opposed to ethno-linguistic fractionalization. A possible reason for why the latter is not contagious is that ethnic groups are exogenous and they emerge rather than are created. Languages, however, can be created, adopted, spread or dominated.

Controlling for spatial dependence also made all the independent variables, except colonial penetration, insignificant. This can be explained by the fact that all the independent 
variables are spatially correlated. All of them are measures of colonial rule and are directly related to colonial. Thus the geographic weight matrix therefore captures and removes this spatial correlation making these variables insignificant. Colonial penetration (GNP/GDP), the only independent variable significant is an indirect measure of colonial rule. Thus, we are still able to capture the indirect effect of colonial penetration on both measures of fractionalization.

Finally institutions seem to matter for linguistic fractionalization but not ethno-linguistic fraction fractionalization. This supports Leeson (2005) that bad institutions exacerbate fractionalization. Controlling for institutions in the linguistic fractionalization regressions makes the measures of colonization significant and the coefficients of rho significant in Table 3.1 and Table 3.2 respectively. This can be explained by the fact that while people can change their language or adopt other languages, it is difficult for them, if not impossible, to change their ethnicity or race no matter how good institutions become. This ethnicity (racial) component in the ethno-linguistic fractionalization measure makes it insensitive or inversely sensitive to institutions.

\subsection{Is there a Possibility of Linguistic Homogeneity in Post-colonial Africa?}

\subsubsection{Political and or Economic Integration}

Though one cannot say for certain whether ethno-linguistic fractions can reduce enough in Africa after the harms caused by colonial rule, looking at what is going on other continents suggests that there is a possibility. Chiswick (2008) documents that English is becoming a "lingua franca" in Europe following the reduction of legal barriers that now facilitates the movement of people and the removal of non-tariff and tariff barriers that facilitates the free mobility of goods (trade) across EU countries. 
If this EU paragon could be epitomized in Africa, free trade and free mobility of economic agents could call for, if not result in, a lingua franca. While this conclusion is feasible I do not want to hasten to suggest what language that would be. While such an economic integration alone could work the magic that could have happened in an uninterrupted precolonial Africa the choice of this new language now may be easier in the presence political integration as well, where individuals would view the speaking of such language as a sign of demonstrating patriotism or nationalism.

This though, in my view will be more difficult than, if not as difficult as, implementing an economic integration. In other words there are benefits as well as costs associated with achieving linguistic homogeneity now as, if not more than, it was in pre-colonial Africa.

\subsubsection{Costs and Benefits of Implementing Policies that could Reduce Ethno-linguistic}

\section{Fractionalization}

The costs associated with implementing an economic integration that will increase free mobility of people and goods in Africa today should not be different from similar ones executed in other parts of the world. Most governments will fear the loss of revenues such as customs duties (export duties and import duties). However, governments can make up for this by increasing excise duties such as production taxes, sales taxes, value added taxes, and sin tax, among others.

Another problem is that most African countries are among the most corrupt countries in the world, and top government officials who have a stake in these duties may rather prefer these colonial barriers, now official barriers to stay. Suffice it to mention here that attempts to establish economic unions such as the Economic Union of West African States (ECOWAS) have been underway for some time now. 
Another cost some Africans would have to bear in promoting one language on the continent or in their countries (if one is to be chosen instead of a dominant one or a few dominant ones emerging naturally) will be to let go their language for another country's. While Chiswick (2008) implies that becoming proficient in the wider society's language does not (and should not) give rise to negative connotations about one's own language or culture, the temptation to see it that way could be minimized if economic integration comes with political integration where all members see all resources of the union, including the chosen language, as belonging to everyone in the in union.

Other costs of linguistic homogeneity include the cost of schooling (to non-native speakers of the chosen language) needed to learn such a language unless it naturally evolved. If this comes with a political integration, it should be possible for the central government to sponsor such training and education.

Benefits associated with linguistic homogeneity in Africa include all the benefits mentioned above (obtainable in pre-colonial setting) and the following. Chiswick (2008) suggests that adopting the language of a larger community imply that one would be exposed a wide range of opportunities including economic, social and civic opportunities. This means that ethno-linguistic homogeneity in Africa will make an average African, who once was limited to the facilities of its small country will now have a choice where to live and or work.

Alesina, Devleeschauwer, Kurlat, Easterly and Wacziarg (2003) find that linguistic fractionalization is strongly negatively related to growth. This means that policies, such as economic integration and political integration, that will reduce linguistic fractionalization in Africa will increase growth as well. That means, though some people will have to give up their language, this will lead to economic development. 
This chapter finds a positive relationship between colonization (including colonial barriers) in African countries and ethno-linguistic fractionalization. This means that polices such as the removal of colonial (trade) barriers will increase trade, reduce linguistic fractionalization which will in turn increase growth in Africa. This is the main focus or argument of this chapter.

\subsection{Conclusion}

The findings of this chapter show that the length of colonization actually worsened the prevalence of linguistic fractionalization and ethno-linguistic fractionalization in Africa instead of mitigating it. This is supported by the results of this chapter which show that the number of years a country was colonized has a positive impact on the linguistic and ethno-linguistic fractionalization of the country.

The results also support the view of Leeson (2005) that bad institutions worsen fractionalization and that this is the reason for the increasing fractionalization and poor growth in Africa. Apart from the division of the continent into colonies, different foreign languages and institutions introduced by colonial rulers made it difficult for Africa to integrate. The chapter suggests that the success of Africa in mitigating or eradicating the effects of linguistic fractionalization and ethno-linguistic fractionalization in Africa depends on the emergence of economic and political integration of the continent. 
Table 3.1. OLS (with and without institutions)

\begin{tabular}{|c|c|c|c|c|}
\hline \multirow[b]{2}{*}{$\begin{array}{l}\text { Independent } \\
\text { Variable }\end{array}$} & \multicolumn{4}{|c|}{ Dependent Variable } \\
\hline & $\begin{array}{l}\text { Ethno-Linguistic } \\
\text { Fractionalization }\end{array}$ & $\begin{array}{c}\text { Linguistic } \\
\text { Fractionalization }\end{array}$ & $\begin{array}{l}\text { Ethno-Linguistic } \\
\text { Fractionalization }\end{array}$ & $\begin{array}{l}\text { Linguistic } \\
\text { Fractionalization }\end{array}$ \\
\hline Constant & $\begin{array}{l}284.697 * * * \\
(3.98)\end{array}$ & $\begin{array}{l}2.910 * * * \\
(3.65)\end{array}$ & $\begin{array}{l}251.409 * * * \\
(-0.18)\end{array}$ & $\begin{array}{l}1.626 * * \\
(2.23)\end{array}$ \\
\hline $\begin{array}{l}\text { Colonial Rule } \\
\text { (no. of year) }\end{array}$ & $\begin{array}{l}0.208 \\
(1.62) \\
\end{array}$ & $\begin{array}{l}0.003 * * \\
(2.14) \\
\end{array}$ & $\begin{array}{l}0.140^{*} \\
(1.67)\end{array}$ & $\begin{array}{l}0.0002 \\
(0.25) \\
\end{array}$ \\
\hline Institutions & $\begin{array}{l}-5.153 \\
(-0.76)\end{array}$ & $\begin{array}{l}-0.202 * * * \\
(-2.63)\end{array}$ & & \\
\hline $\begin{array}{l}\text { Colonial } \\
\text { Penetration }\end{array}$ & $\begin{array}{l}-2.222 * * * \\
(-3.04)\end{array}$ & $\begin{array}{l}-0.025 * * * \\
(-3.21)\end{array}$ & $\begin{array}{l}-1.890 * * * \\
(-3.47)\end{array}$ & $\begin{array}{l}-0.013 * \\
(-1.73)\end{array}$ \\
\hline $\begin{array}{l}\text { British Colonial } \\
\text { Dummy }\end{array}$ & $\begin{array}{l}-15.526 \\
(-0.87) \\
\end{array}$ & $\begin{array}{l}0.642 * * \\
(1.99) \\
\end{array}$ & $\begin{array}{l}-24.043^{*} \\
(1.67) \\
\end{array}$ & $\begin{array}{l}0.306 \\
(1.03) \\
\end{array}$ \\
\hline $\begin{array}{l}\text { French Colonial } \\
\text { Dummy }\end{array}$ & $\begin{array}{l}1.684 \\
(0.11) \\
\end{array}$ & $\begin{array}{l}0.554^{*} \\
(1.78)\end{array}$ & $\begin{array}{l}-3.888 \\
(-0.31) \\
\end{array}$ & $\begin{array}{l}0.336 \\
(1.13) \\
\end{array}$ \\
\hline $\begin{array}{l}\text { Belgium Colonial } \\
\text { Dummy }\end{array}$ & $\begin{array}{l}-3.078 \\
(-0.15)\end{array}$ & $\begin{array}{l}0.338 \\
(0.79)\end{array}$ & $\begin{array}{l}-4.257 \\
(-0.22)\end{array}$ & $\begin{array}{l}0.263 \\
(0.73)\end{array}$ \\
\hline Border dummy & $\begin{array}{l}-2.756 \\
(-0.27) \\
\end{array}$ & $\begin{array}{l}0.030 \\
(0.20) \\
\end{array}$ & $\begin{array}{l}-5.001 \\
(-0.52) \\
\end{array}$ & $\begin{array}{l}-0.063 \\
(-0.40)\end{array}$ \\
\hline R-Squared & 0.26 & 0.35 & 0.24 & 0.15 \\
\hline
\end{tabular}

Notes: t-statistics in parentheses; asterisks indicate significance as follows: $* * *=1 \%, * *=5 \%, *=10 \%$.

Variable description, descriptive statistics, and sources can be found in Appendix 5. 
Table 3.2. SAR (with and without institutions)

\begin{tabular}{|c|c|c|c|c|}
\hline \multirow[b]{3}{*}{$\begin{array}{l}\text { Independent } \\
\text { Variable }\end{array}$} & \multicolumn{4}{|c|}{ Dependent Variable } \\
\hline & \multicolumn{4}{|c|}{ Spatial Error Model (SAR) } \\
\hline & $\begin{array}{c}\text { Linguistic } \\
\text { Fractionalization }\end{array}$ & $\begin{array}{l}\text { Ethno-Linguistic } \\
\text { Fractionalization }\end{array}$ & $\begin{array}{l}\text { Linguistic } \\
\text { Fractionalization }\end{array}$ & $\begin{array}{l}\text { Ethno-Linguistic } \\
\text { Fractionalization }\end{array}$ \\
\hline Constant & $\begin{array}{l}0.246 \\
(1.595)\end{array}$ & $\begin{array}{l}40.984 * * * \\
(2.778)\end{array}$ & $\begin{array}{l}0.246^{*} \\
(1.710)\end{array}$ & $\begin{array}{l}48.862 * * * \\
(3.458)\end{array}$ \\
\hline Rho & $\begin{array}{l}0.317 * * * \\
(2.49)\end{array}$ & $\begin{array}{l}0.025 \\
(0.193)\end{array}$ & $\begin{array}{l}0.312 * * * \\
(2.424)\end{array}$ & $\begin{array}{l}0.051 \\
(0.384)\end{array}$ \\
\hline $\begin{array}{l}\text { Colonial Rule } \\
\text { (no. of year) }\end{array}$ & $\begin{array}{l}0.0005 \\
(1.065) \\
\end{array}$ & $\begin{array}{l}0.026 \\
(0.661)\end{array}$ & $\begin{array}{l}0.0004 \\
(1.081) \\
\end{array}$ & $\begin{array}{l}0.041 \\
(1.033) \\
\end{array}$ \\
\hline Institutions & $\begin{array}{l}-0.002 \\
(-0.039)\end{array}$ & $\begin{array}{l}6.263 \\
(1.55)\end{array}$ & & \\
\hline $\begin{array}{l}\text { Colonial } \\
\text { Penetration }\end{array}$ & $\begin{array}{l}-0.0004 \\
(-0.400) \\
\end{array}$ & $\begin{array}{l}0.045 \\
(0.482) \\
\end{array}$ & $\begin{array}{l}-0.0004 \\
(-0.399) \\
\end{array}$ & $\begin{array}{l}0.023 \\
(0.245) \\
\end{array}$ \\
\hline $\begin{array}{l}\text { British Colonial } \\
\text { Dummy }\end{array}$ & $\begin{array}{l}0.251 * \\
(1.75)\end{array}$ & $\begin{array}{l}-12.604 \\
(-0.949)\end{array}$ & $\begin{array}{l}0.249 * * \\
(1.945)\end{array}$ & $\begin{array}{l}-3.564 \\
(-0.293)\end{array}$ \\
\hline $\begin{array}{l}\text { French Colonial } \\
\text { Dummy }\end{array}$ & $\begin{array}{l}0.210^{*} \\
(1.62)\end{array}$ & $\begin{array}{r}5.778 \\
(0.478) \\
\end{array}$ & $\begin{array}{l}0.209 * \\
(1.671)\end{array}$ & $\begin{array}{l}10.661 \\
(0.894) \\
\end{array}$ \\
\hline $\begin{array}{l}\text { Belgium Colonial } \\
\text { Dummy }\end{array}$ & $\begin{array}{l}-0.028 \\
(-0.146)\end{array}$ & $\begin{array}{l}6.778 \\
(0.371)\end{array}$ & $\begin{array}{l}-0.028 \\
(-0.144)\end{array}$ & $\begin{array}{l}5.672 \\
(0.303)\end{array}$ \\
\hline Border dummy & $\begin{array}{l}0.027 \\
(0.270)\end{array}$ & $\begin{array}{l}0.024 \\
(0.194)\end{array}$ & $\begin{array}{l}0.027 \\
(0.270)\end{array}$ & $\begin{array}{l}3.445 \\
(0.36)\end{array}$ \\
\hline R-Squared & 0.17 & 0.12 & 0.17 & 0.08 \\
\hline
\end{tabular}

Notes: t-statistics in parentheses; asterisks indicate significance as follows: $* * *=1 \%, * *=5 \%, *=10 \%$

Variable description, descriptive statistics, and sources can be found in Appendix 5. 


\section{CHAPTER 5}

\section{Conclusion}

The dissertation focuses on economic contagion in financial and international development. Each chapter is based on an idea in either in financial economics or international economics or both. The main channels of contagion found in this study are trade, geography and financial linkages.

Chapter 2 explores contagion in exchange market pressure, currency crisis and currency stability and identifies trade linkages, geographic linkages and financial markets as the channels of contagion. It models contagion using two spatial econometric models namely spatial error mode and spatial autoregressive model. A panel of 119 countries is considered in this chapter. It finds that trade linkages are more effective channels of contagion than geography in currency crisis, currency stability and exchange market pressure in general.

The findings of chapter 2 also suggests that there stable currency periods are more contagious than crisis periods. This implies that enforcing trade will do more good than harm to a country. Another significant contribution of this chapter is that, though trade, is the major channel of contagion in currency crisis, the geographic channel should not be ignored. It suggests that the geography channel or effect help explain why currency crises are largely regional.

Chapter 3 estimates contagion in financial development both at levels and at first difference. Using spatial error model the paper investigate whether financial development is contagious. The chapter investigates whether changes of financial development are contagious. The channels of contagion in this chapter are trade, geography and financial linkages. It finds that financial linkages are a better channel of transmission than trade and geography. The findings of the chapter also confirm those of other studies that legal uncertainty and bureaucratic delays also determine financial development. 
Chapter 4 attempts to examine what has made it difficult for a single language to spread through the African continent or for the evolution of a lingua franca in Africa. It explains that trade would have been the main means by which this could have happened, but the process got interrupted by colonial rule. It explains that while Pre-colonial Africa would have faced costs and benefits in adopting a single language, the benefits did outweigh the costs. However, colonization increased the cost and this makes it difficult, if not impossible, for post-colonial Africa to reduce their levels of ethno-linguistic fractionalization or linguistic fractionalization, important determinants of growth. It suggests that the only way the process could get restored is a political and or economic integration of African countries. These recommendations are however not without a cost and it may take a reasonably long time for Africans to pay the price in order to reap the benefits of integration.

In conclusion, the dissertation finds that, trade, financial linkages and geography are very important transmission mechanisms of contagious economic events. Addressing these channels strategically can minimize the spread of negative shocks and the costs they bring and maximize the spread of positive economic shocks and lead to an increased growth of countries around the world, especially developing countries. In other words, strong economic unions as well as trade liberalization in physical assets and financial assets can be important tools used especially by poor countries to harness, attract, or catch the positive externalities coming from other countries around them. These same tools can be used to repel, reduce, neutralize or undo negative spillovers countries would otherwise have to consume in the world community. 


\section{References}

Aghion, Philippe, Bacchetta, Philippe and Abhijit Banerjee (2000), "A Simple Model of Monetary Policy and Currency Crises." European Economic Review, 44(4-6), 728-38.

Aghion, Philippe, Howitt, Peter and Mayer-Foulkes, David (2004), "The Effect of Financial Development on Convergence: Theory and Evidence," NBER Working Paper No. W10358.

Alesina Alberto, Devleescjauwer Arnaud, Easterly William, Kurlat Sergio, Wacziarg Romain (2003), "Fractionalization,” Journal of Economic Growth 8: 155-194.

Anselin, Luc. (1988). In Spatial Econometrics: Methods and Models. Dordrecht: Kluwer Academic Publishers.

Anselin, Luc and Moreno, Rosina (2003), "Properties of tests for spatial error Components," Regional Science and Urban Economics, Elsevier, 33(5), 595-618.

Baig, Taimur and Ilan, Goldfajn (1999), "Financial Market Contagion in the Asian Crisis," International Monetary Fund Staff Papers, 46, No 2: 167-95.

Barro, Robert J. (1991), "Economic Growth in a Cross Section of Countries," Quarterly Journal of Economics, CVI , 407-43.

Becker, Bo and Sivadasan, Jagadeesh (2006), "The Effect of Financial Development on the Investment Cash Flow Relationship: Cross-Country Evidence from Europe," ECB Working Paper No. 689.

Bekaert, G., Harvey, C., and Lundblad, C., (2005), "Does Financial Liberalization Spur Growth?," Journal of Financial Economics, 77, 3-55.

Bekaert, G., Harvey, C., Lundblad, C., and Siegel, S., (2007), "Global Growth Opportunities and Market Integration”, Journal of Finance, 62, 3, 1081-1135.

Bertocchi Graziella and Fabio Canova (2002), "Did colonization matter for growth? An Empirical exploration into the historical causes of Africa's underdevelopment," European Economic Review, 46, 1851-1871.

Bown, Chad P., Crowley, Meredith, McCulloch, Racheland, Nakajima, Daisuke J. (2005), "The U.S. Trade Deficit: Made in China?" Economic Perspectives, Federal Reserve Bank of Chicago, Q IV, 2-18. 
Calvo, Guillermo and Mendoza, Enrique (1996), "Mexico's Balance of Payment Crisis: A Chronic of Death Foretold," Journal of International Economics, 41, 235-64.

Chiodo, Abbigail and M. Owyang (2002), "A Case Study of Currency Crises: The Russian Default of 1998," Federal Reserve Bank of St. Louis Review, 84(6), 7-17.

Chiswick, Barry R. (2008), “The Economics of Language: An Introduction and Overview,” IZA Discussion Papers, 3568, Institute for the Study of Labor (IZA).

Cohen, A. (1969), "Customs and Politics in Urban Africa," University of California Press.

Collier Paul (1999), “Ethnicity, Politics, and Economics Performance,” World Bank Mimeo.

Cunning David and Marianne Fay (1993), "The Effect of Transportation Network on Growth", Discussion Papers Series, Columbia University, Dept. of Economics.

Cvetanovic, Slobodan (2006), "The Role of institutional investors in Financial Development of European Accession Countries," Economics and Organization, 3, 1, 1-11.

Desai, Mihir A., Foley, C. Fritz and Hines Jr., James R. (2004), "Capital Controls, Liberalizations, and Foreign Direct Investment,” NBER Working Paper No. W10337.

de Soto, Hernando (2000), "The Mystery of Capital: Why Capitalism Triumphs in the West and Fails Everywhere Else," New York: Basic Books.

Dooley, Michael (1997), “A Model of Crises in Emerging Markets," NBER Working Paper, No 6300 .

Dutta, Nabamita and Sanjukta Roy, "The Impact of Foreign Direct Investment on Press Freedom," Forthcoming in Kyklos.

Edwards, Sebastian (2000), "Interest Rates, Contagion and Capital Controls," NBER Working Papers 7801, 7801, National Bureau of Economic Research, Inc.

Eichengreen, Barry, Rose, Andrew K. and Wyplosz, Charles (1996), "Contagious Currency Crises," Scandinavian Journal of Economics, 1996, Vol. 98 Issue 4, p463, 22p.

Easterly William (2001), “Can institutions resolve ethnic conflicts?” Economic Development And Cultural Change, 49: 687-706.

Easterly William and Ross Levine (1997), "Africa's Growth Tragedy: Policies and Ethnic Ethnic Divisions,” Quarterly Journal of Economics, 112: 1203-1250. 
Flood, Robert P. and Garber, Peter M. (1984), "Collapsing Exchange Rate Regimes: Some Linear Examples,” Journal of International Economics, 17(1-2), 1-13.

Grier R.M. (1999), “Colonial legacies and economic growth,” Public Choice 98, 317-335.

Johnson, Simon, John McMillan, and Christopher Woodruff (2002), "Property Rights and Finance," American Economic Review, 92, 1335-1356.

Knack Stephen and Philip Keefer (1997), "Does Social Capital Have an Economic Payoff? A Cross-country Investigation," Quarterly Journal of Economics, CXII: 4, 1251-1288.

Kaminsky, Graciela L. and Reinhart, Carmen M. (2000), "On Crises, Contagion and Confusion," Journal of International Economics, Elsevier, vol. 51(1), 145-168.

Kaminsky, Graciela L. and Reinhart, Carmen M. (1996), "The twin crises: The causes of banking and balance-of-payments problems," International Finance Discussion Papers 544, Board of Governors of the Federal Reserve System (U.S.).

Krugman, Paul (1979), “A model of Balance-of-Payment Crises," Journal of Money Credit and Banking, 11(3), 311-25.

Krugman, Paul (1999), "Balance sheets, the transfer problem and financial Crises," forthcoming in Robert Flood Festschrift volume.

Leeson T. Peter (2005), “Endogenizing Fractionalization,” Journal of Institutional Economics 1: $1,75-98$.

Leeson, Peter T. and Sobel, Russell (2006), “Contagious Capitalism,” West Virginia University Working Paper, No. 06-04.

Lesage, James P. and R. Kelly Pace (eds.), Introduction to Advances in Econometrics: Volume 18: Spatial and Spatiotemporal Econometrics. Oxford: Elservier Ltd, (2004): 1-32.

Lipsey, Robert (2000), "Interpreting Developed Countries' Foreign Direct Investment," NBER Working Papers 7810.

Luigi Zingales, Raghuram G. Rajan, ( 2003b), "Banks and Markets: The Changing of European Finance," NBER Working Papers 9595, National Bureau of Economic Research, Inc.

Mauro Paolo (1995), "Corruption and Growth,” Quarterly Journal of Economics, CX: 681-712.

Niels Hermes; Robert Lensink (2003), “Foreign Direct Investment, Financial Develop- 
ment and Economic Growth,” Journal of Development Studies, 40, 142-163.

Obstfeld, Maurice (1986), "Rational Self-fulfilling Balance-of-Payment Crises," American Economic Review, 76(1), 45-73.

Pesenti, Paolo A. and Tille, Cedric (2000), "The Economics of Currency Crises and Contagion," Federal Reserve Bank of New York Economic Policy Review, 6(3), 3 - 16.

Rajan R. G., and Zingales, L. (2003a), "The Great Reversals: The Politics of Financial Development inthe 20th Century," Journal of Financial Economics, forthcoming.

Reuven, Glick and Rose, Andrew K. (1999), "Contagion and trade: Why are currency crises regional?” Journal of International Money and Finance, Elsevier, vol. 18(4), 603-617.

Rioja, Felix and Neven Valev (2004). "Finance and the Sources of Growth at Various Stages of Economic Development," Economic Inquiry, Oxford University Press, 42(1), 127-140.

Rubinstein, A., (1998). “Economics and Language,” 14-98, Tel Aviv.

Smith, Adam (1776), "An Inquiry into the Nature and Causes of the Wealth of Nations" Audited by W. B. Todd (Oxford: Clarendon, Press 1976).

Stulz, Rene M. (2005), "The Limits of Financial Globalization," Journal of Finance, 60(4), 1595-1638.

Tiebout, Charles (1956), "A Pure Theory of Local Expenditures," Journal of Political Economy, 64, 416-424.

Thornton, J. (1995), "Africa and Africans in the Making of the Atlantic World," 1400-1680, London: Cambridge University Press.

Vally Koubi (2008), "On the Determinants of Financial Development and Stock Returns," Journal of Money, Investment and Banking, ISSN 1450-288X Issue 1.

Vansina, J. (1968), "Long-distance trade-routs in central Africa," in R. Collins (ed.), Problems in African History, Englewood Cliffs, NJ: Princeton-Hall. 
Appendix 1: Variable Description, Descriptive Statistics, and Sources for chapter 3

\begin{tabular}{|c|c|c|}
\hline \multirow{2}{*}{\multicolumn{3}{|c|}{ Variable Name (source) }} \\
\hline & & \\
\hline $\begin{array}{l}\text { EMP - Exchange market } \\
\text { Pressure (2) }\end{array}$ & $\begin{array}{l}\text { A linear combination of exchange rates and } \\
\text { international reserves }\end{array}$ & $0.767(25.484)$ \\
\hline Currency Crises (2) & Excess EMP (\%) & $2.400(13.822)$ \\
\hline Currency Stability (2) & Absolute Value EMP shortfall (\%) & $0.013(0.020)$ \\
\hline Exchange Rate (2) & $\begin{array}{l}\text { Official exchange rate (LCU per DM, period } \\
\text { average) }\end{array}$ & \\
\hline $\begin{array}{l}\text { Independent } \\
\text { Variables: }\end{array}$ & & $-3.418(6.359)$ \\
\hline Current Account (2) & Annual current account per GDP $(\%)$ & $-3.681(83.069)$ \\
\hline Domestic Credit (1) & $\begin{array}{l}\text { Annual growth rate of Domestic credit provided } \\
\text { by banking sector per GDP }(\%)\end{array}$ & $11.155(45.362)$ \\
\hline M2 (1) & Money and quasi money to total reserve ratio & \\
\hline CPI (1) & Annual growth of consumer Prices (\% ) & $0.375(6.192)$ \\
\hline GDP Growth (1) & Annual growth rate of GDP (\%) & $4.203(5.527)$ \\
\hline Unemployment (1) & Unemployment, total (\% of total labor force) & \\
\hline $\begin{array}{l}\text { Geographic } \\
\text { Neighbors(4) }\end{array}$ & $\begin{array}{l}\text { Number of neighbors a country has based on } \\
\text { first-order contiguity }\end{array}$ & \\
\hline
\end{tabular}

1. World Development Indicator; The World Bank Databases

2. Direction Of Trade; IMF Databases

3. International Financial Statistics, IMF Databases

4. CIA, The World Fact Book 


\section{Appendix 2: List of Countries for chapter 3}

\begin{tabular}{l|l|l|} 
Afghanistan, Islamic Republic of & Ghana & New Zealand \\
Albania & Greece & Nicaragua \\
Algeria & Guatemala & Niger \\
Argentina & Guinea & Nigeria \\
Australia & Guyana & Norway \\
Austria & Haiti & Oman \\
Bangladesh & Honduras & Pakistan \\
Belgium & China, P.R.: Hong & Panama \\
Benin & Kong & Paraguay \\
Bolivia & Hungary & Peru \\
Brazil & Iceland & Philippines \\
Bulgaria & India & Poland \\
Burkina Faso & Indonesia & Portugal \\
Burundi & Iran, Islamic & Romania \\
Cameroon & Republic of & Russian Federation \\
Canada & Iraq & Rwanda \\
Chile & Ireland & Saudi Arabia \\
China, P.R.: Mainland & Israel & Senegal \\
Colombia & Italy & Serbia and Montenegro \\
Congo, Democratic Republic of & Jamaica & Sierra Leone \\
Congo, Republic of & Japan & Singapore \\
Costa Rica & Jordan & Somalia \\
Côte d'Ivoire & Kenya & South Africa \\
Cuba & Korea, Democratic & Spain \\
Cyprus & People's Rep. of & Sri Lanka \\
Czech Republic & Korea, Republic of & Sudan \\
Denmark & Sebanon & Sweden \\
Dominican Republic & Switzerland \\
Ecuador & Liberia & Tanzania \\
Egypt & Madagascar & Thailand \\
El Salvador & Malawi & Togo \\
Equatorial Guinea & Trinidad and Tobago \\
Estonia & Malaysia & Tunisia \\
Ethiopia & Mali & Turkey \\
Fiji & United Kingdom \\
Finland & Mauritania & United States \\
France & Uruguay \\
Gabon & Mauritius & Venezuela \\
Gambia, The & Mexico & \\
Georgia & Mongolia & \\
Germany & Morocco & \\
& Mozambique & \\
\hline
\end{tabular}




\begin{tabular}{|c|c|c|}
\hline $\begin{array}{l}\text { Variable } \\
\text { Name (source) }\end{array}$ & Description & $\begin{array}{l}\text { Mean (Std. } \\
\text { Dev.) }\end{array}$ \\
\hline \multicolumn{3}{|l|}{ Dependent Variables: } \\
\hline $\begin{array}{l}\text { Financial Development - } \\
\text { Private Credit to } \\
\text { the Private Sector } \\
\text { (1) }\end{array}$ & $\begin{array}{l}\text { Domestic Credit to the Private Sector (\% GDP) } \\
\text { Stock Market Total Value Traded (\% GDP) } \\
\text { Private Credit by the Banking Sector (\% GDP) }\end{array}$ & $\begin{array}{l}0.473(0.384) \\
25.052(32.749) \\
0.805(3.140)\end{array}$ \\
\hline \multicolumn{3}{|l|}{ Independent Variables: } \\
\hline Per Capita Income (1) & GDP per capita (constant 2000 US\$) & $\begin{array}{l}7.0341 \mathrm{e}+003 \\
(8.9556 \mathrm{e}+003)\end{array}$ \\
\hline Bureaucratic Quality (5) & Index of bureaucratic (1-10): The higher the better. & $3.304(1.743)$ \\
\hline Risk of Expropriation (5) & $\begin{array}{l}\text { Index of the risk of outright confiscation of private } \\
\text { investment (1-10). The higher the better. }\end{array}$ & $7.239(2.796)$ \\
\hline $\begin{array}{l}\text { Risk of repudiation of } \\
\text { contracts (5) }\end{array}$ & $\begin{array}{l}\text { Index of changes in government and or its behavior } \\
(1-10) \text {. The higher the better. }\end{array}$ & $6.602(2.778)$ \\
\hline Legal Environment (5) & $\begin{array}{l}\text { Index of legal uncertainty. Sum of the risks of } \\
\text { expropriation and repudiation of contracts }(2-20) \text {. } \\
\text { The higher the lower the legal uncertainty. }\end{array}$ & $13.841(5.502)$ \\
\hline Geographic Neighbors(4) & $\begin{array}{l}\text { A country's neighbor based on queen first order } \\
\text { contiguity criteria }\end{array}$ & \\
\hline Trade Partners (2) & Countries that engage in bilateral trade & \\
\hline FDI Partners (3) & Countries that receive FDI inflows from each other & \\
\hline
\end{tabular}

1. World Development Indicator; The World Bank Databases

2. Direction Of Trade; IMF Databases

3. OECD Databases

4. CIA, The World Fact Book

5. International Country Risk Guide; ICRG Dataset 


\begin{tabular}{|c|c|c|}
\hline Algeria & Germany & Niger \\
\hline Argentina & Ghana & Nigeria \\
\hline Australia & Greece & Norway \\
\hline Austria & Guatemala & Pakistan \\
\hline Bahamas, The & Haiti & Panama \\
\hline Bahrain & Honduras & Paraguay \\
\hline Bangladesh & Hong Kong, & Peru \\
\hline Barbados & China & Philippines \\
\hline Belgium & Hungary & Portugal \\
\hline Belize & Iceland & Senegal \\
\hline Benin & India & Sierra Leone \\
\hline Bolivia & Indonesia & Singapore \\
\hline Brazil & Iran, Islamic & Slovakia \\
\hline Burundi & Rep. & South Africa \\
\hline Cameroon & Ireland & Spain \\
\hline Canada & Israel & Sri Lanka \\
\hline Chile & Italy & Sweden \\
\hline China & Jamaica & Switzerland \\
\hline Czech Republic & Japan & Tanzania \\
\hline Colombia & Jordan & Thailand \\
\hline Congo, Dem. & Kenya & Togo \\
\hline Rep. & Korea, Rep. & Trinidad and \\
\hline Congo, Rep. & Kuwait & Tobago \\
\hline Costa Rica & Luxemburg & Tunisia \\
\hline Cote d'Ivoire & Madagascar & Turkey \\
\hline Cyprus & Malawi & Uganda \\
\hline Denmark & Malaysia & United Kingdom \\
\hline Dominican & Mali & United Arab \\
\hline Republic & Malta & Emirates \\
\hline Ecuador & Mauritius & Uruguay \\
\hline Egypt, Arab & Mexico & United States \\
\hline Rep. & Morocco & Venezuela, RB \\
\hline El Salvador & Myanmar & Zambia \\
\hline Fiji & Nepal & Zimbabwe \\
\hline Finland & Netherlands & \\
\hline France & New Zealand & \\
\hline Gabon & Nicaragua & \\
\hline
\end{tabular}




\section{Appendix 5: Variable Description, Descriptive Statistics, and Sources}

\begin{tabular}{|c|c|c|}
\hline Variable Name (source) & Description & Mean (Std. Dev.) \\
\hline \multicolumn{3}{|l|}{ Dependent Variables: } \\
\hline Linguistic Fractionalization(3) & Index of linguistic diversity (\%) & $0.623(0.291)$ \\
\hline Ethno-linguistic Fractionalization(6) & Index of ethnic and linguistic diversity (\% ) & $0.616(0.26707)$ \\
\hline Independent Variables: & & \\
\hline Colonial Penetration(1) & $\begin{array}{l}\text { GNP/GDP computed for } 1960 \text { : The lower the value } \\
\text { the higher the extent of colonial penetration or } \\
\text { drain. } \\
\text { Index of institutional quality computed as an }\end{array}$ & $98.993(4.341)$ \\
\hline Institution (5) & $\begin{array}{l}\text { average of three variables (bureaucratic quality, } \\
\text { risk of expropriation, and the risk of repudiation of } \\
\text { contracts ): (1-10); the higher the better. }\end{array}$ & $2.327(0.993)$ \\
\hline Colonial Rule (4) & $\begin{array}{l}\text { Number of years a country has been colonized by } \\
\text { all possible colonial Masters (years) }\end{array}$ & \\
\hline Border dummy & $\begin{array}{l}\text { A dummy specifying whether a country's borders } \\
\text { were created by colonial masters }\end{array}$ & $100.000(120.9017)$ \\
\hline Colonial Dummy & $\begin{array}{l}\text { A dummy showing which colonial master } \\
\text { colonized a country }\end{array}$ & \\
\hline
\end{tabular}

1. World Development Indicator; The World Bank Databases

2. Direction Of Trade; IMF Databases

3. Alesina et al. (2003) Dataset

4. CIA, The World Fact Book

5. International Country Risk Guide; ICRG Dataset

6. Elf Dataset 
Appendix 6: List of Countries

\begin{tabular}{|l|l|l|}
\hline & & \\
Algeria & Equatorial & Morocco \\
Benin & Guinea & Mozambiqe \\
Burkina Faso & Ethiopia & Niger \\
Burundi & Gabon & Nigeria \\
Cameroon & Gambia, The & Rwanda \\
Cape Verde & Ghana & Senegal \\
Central African Repul & Guinea & Sierra \\
Chad & Bissau & Leone \\
Comoros & Kenya & Somalia \\
Congo, Rep. & Liberia & South \\
Of the & Libya & Africa \\
Congo, Dem. & Madagascar & Sudan \\
Rep. Of the & Malawi & Tanzania \\
Cote d'lvoire & Malawi & Togo \\
Djibouti & Mauritania & Uganda \\
Egypt & Mauritius & Zambia \\
& & Zimbabwe \\
\hline
\end{tabular}




\section{JOHN DOGBEY}

VITA

Department of Economics

660 Protzman Street Apt D

West Virginia University

Morgantown, WV 26505

Morgantown, WV 26505-6025

Cell Phone: (304) 685-4116

(304) 293-7964

Email: john.dogbey@mail.wvu.edu

\section{PERSONAL:}

Single

Nationality: Ghana

\section{EDUCATION:}

Doctor of Philosophy in Economics, August 2009

West Virginia University, Morgantown WV 26506

Major Areas: International Economics

Minor Areas: Financial Economics, Spatial Econometrics

Dissertation Title: "Spillover Effects in Financial and International Development."

Chair: Russell S. Sobel

Master of Arts in Economics, August 2005

Youngstown State University, Youngstown OH, 44555

Bachelor of Arts in Economics, Second Class Upper, May 2002

University of Ghana, Legon, Accra Ghana

\section{TEACHING EXPERIENCE:}

West Virginia University, Department of Economics, Fall 2005-Present

Instructor, Principles of Macroeconomics: Four Sections

Instructor, Survey of Finance: One Section (Online)

Instructor, Intermediate Microeconomics: One Section

Instructor, Money and Banking: One Section

Instructor, Fundamentals of Corporate Finance: One Section 


\section{RESEARCH EXPERIENCE:}

\section{Youngstown State University, Department of Economics, Summer 2005}

\section{Research Assistant to Ou Hu}

My responsibilities included helping with citations for literature reviews.

\section{West Virginia University, Department of Economics, Fall 2005-Present}

\section{RESEARCH IN PROGRESS:}

Dogbey, John. "Currency Crises and Exchange Market Pressure - Contagion, Trade and Geography." Under Review.

Dogbey, John. “The Spread of Financial Development.” Submitted.

Dogbey, John. "Does Environmental Pollution Replicate the Transfer Problem? - The Role of Trade." Working Paper.

Dogbey, John, “Is Ethno-Linguistic Fractionalization Perpetuated in Africa?" Working Paper.

Dogbey, John. "Extraction, Constitutional Constraints and Political Stability: A Case

Study of the Developing World." Working Paper.

Dogbey, John. "The Impact of Foreign Exchange Availability and Industrial Production On Nigeria’s Imports - A Cointegration Approach.” Working Paper.

Dogbey, John. "Emancipation of Women and Development in Africa." Working Paper.

Dogbey, John. “Trade and Development in Africa: Institutional Explanations.” Working Paper.

Dogbey, John. "Does the Twin Deficit Relationship Hold for the US? - An investigation using Vector Error Correction Model." Working Paper

\section{CONFERENCE PRESENTATION:}

Dogbey, John. "The Spread of Financial Development." Presented at the Association of Private Enterprise Education Meeting, Las Vegas, Nevada, April 2007.

Dogbey, John. "Currency Crises and Exchange Market Pressure - Contagion, Trade and Geography." Presented at the MEA Meeting, Cleveland, OH, March 2009 
Dogbey, John. Session Chair : "Contagion and Default" at the MEA Meeting, Cleveland, OH, March 2009

\section{POSITIONS HELD:}

Treasurer: Thompson Club: (Department of Economics, WVU): 2008-09

Responsibilities included designing ways of raising funds for the association and general financial services.

\section{AWARDS:}

Vickers Advanced Doctoral Student Awards: 2008-09

Given by the department faculty to the graduate student best judged as making remarkable progress in teaching and research, with monetary incentive as well.

Nominated for the Vickers Doctoral Student Teaching Award: 2008-09

\section{EMPLOYMENT EXPERIENCE:}

Ohio University, Athens OH, starting September 2009

Visiting Assistant Professor of Economics

Enasjon Enterprise (Family Business), Accra, Ghana 06/01/2001-07/30/2004

Sales Manager:

My responsibilities included designing of marketing strategies, supervision of the junior staff, coordinating with retailers, taking stock of goods, maintenance of office impress, writing of checks to be approved by the Accountant, reconciling accounts and general administrative supports.

\section{PROFESSIONAL AFFILIATIONS:}

Association of Private Enterprises

American Economic Association

Midwest Economic Association

Southern Economic Association 


\section{REFERENCES:}

Dr. Russell S. Sobel

James Clark Coffman Distinguished Chair

Professor

Department of Economics

West Virginia University

Morgantown, WV 26506

(304) 293-7864

Dr. Subhayu Bandyopadhay

Research Officer

Research Division

Federal Reserve Bank of St. Louis

P.O. Box 442

St. Louis, MO 63166-0442

(314) 444-7425
Stratford Douglas

Associate Professor

Department of Economics

West Virginian University

Morgantown, WV 26506

(304) 293-7863

John

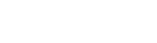

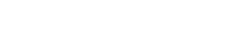

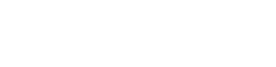

